\title{
The scythridid fauna of the southern Ural Mountains, with description of fourteen new species (Lepidoptera: Scythrididae)
}

\author{
Kari Nupponen, Bengt Å. Bengtsson, Jari-Pekka Kaitila, Timo Nupponen, Jari Junnilainen \& \\ Vladimir Olschwang
}

\begin{abstract}
Nupponen, K., Bengtsson, B. Å., Kaitila, J-P., Nupponen, T., Junnilainen, J. \& Olschwang, V. 2000: The scythridid fauna of the southern Ural Mountains, with description of fourteen new species (Lepidoptera: Scythrididae). - Entomol. Fennica 11: 5-34.
\end{abstract}

\begin{abstract}
A list of 37 species of the family Scythrididae from the southern Ural Mountains is presented. The material was collected during 1996-1999 in five different Finnish - Russian expeditions. Fourteen new species are described by varying combination of authors: Scythris acipenserella K. \& T. Nupponen sp. n., S. aegrella K. Nupponen \& Junnilainen sp. n., S. albisaxella K. \& T. Nupponen sp. n., $S$. arkaimensis Bengtsson sp. n., S. brunneofasciella K. Nupponen \& Junnilainen sp. n., S. cretacella K. \& T. Nupponen, sp. n., S. elenae K. Nupponen sp. n., $S$. eversmanni K. \& T. Nupponen sp. n., S. karinupponeni Bengtsson sp. n., $S$. luxatiella K. Nupponen \& Kaitila sp. n., S. olschwangi K. \& T. Nupponen sp. n., S. perlucidella K. \& T. Nupponen sp. n., S. remexella K. Nupponen \& Kaitila sp. n. and $S$. sublaminella K. \& T. Nupponen sp. n.. One unknown species is menlioned but not described because only a single female is available. In addition, 10 species are reported as new for Russia. The known distribution range of each species is given as well as further notes on some poorly known species.
\end{abstract}

Kari Nupponen, Miniatontie l B 9, FIN-02360 Espoo, Finland Bengt A. Bengtsson, Lokegatan 3, S-38693 Färjestaden, Sweden Jari-Pekka Kaitila, Kannuskuja 8 D 37, FIN-01200 Vantaa, Finland Timo Nupponen, Riilahdentie 5 D 15, FIN-02360 Espoo, Finland Jari Junnilainen, Mahlapolku 3, FIN-01730 Vantaa, Finland Vladimir Olschwang, Nagornaja street 11-32, RUS-620028 Ekaterinburg, Russia

Received 30 April 1999, accepted 26 September 1999

\section{Introduction}

The Ural Mountains form a $2000 \mathrm{~km}$ long natural border between Europe and Asia. The mountains almost reach the Caspian Sea in the south and the Arctic Ocean seashore in the north. It is an old and relatively low mountain range, the high- est elevation in the southern part being $1640 \mathrm{~m}$ (a.s.l.). The biotopes at higher elevation are taiga forests with a few isolated mountain tundra habitats on the highest hilltops. The southernmost part of the Ural Mountains has been reduced to a foothill zone, gradually becoming lowland steppe without any clear border. 
The most important article about the Lepidoptera fauna of the southern Ural Mountains was published by Eversmann (1844). In the beginning of the 20th century there were some collecting activities in that region, but no noteworthy publications exist. Since then, only butterflies have been studied there, and the knowledge of the Microlepidoptera fauna in the southern Ural region has been a blank page during the last one hundred years.

However, despite thorough investigations Eversmann did not mention any records on scythridids in his work. The reason for this lack may be explained from the collecting methods, although some species that fly in sunshine are easy to catch by net. In reality, the scythridid fauna is very rich in the southern Ural region and may include several endemic species. Since Eversmann's days, a considerable part of steppe habitats have been destroyed due to agricultural influence, but large areas are still in original or sub-original condition for investigations.

The political situation in Europe/Asia has made possible visiting remote areas where very few or no lepidopterists have collected in the past. The first author and others have thus been able to travel in unexplored regions of Russia, e.g. in the southern Ural Mountains, and subsequently found several undescribed scythridids. Some of the results have already been published, see Sinev (1993), Sachkov (1995), Bengtsson \& Liška (1996), Bengtsson \& Sutter (1996), Bengtsson (1997a) and Bengtsson (1997b). The Asian scythridid fauna is currently under study and a paper comprising all known data will be published in a few years (Bengtsson, in prep.).

\section{The investigation area, material and methods}

The investigated area is situated in Cheliabinsk and Orenburg oblasts and Bashkiria in the southern Ural Mountains, between $50^{\circ} 40^{\prime} \mathrm{N}-55^{\circ} 01^{\prime} \mathrm{N}$ and $54^{\circ} 26^{\prime} \mathrm{E}-62^{\circ} 06^{\prime} \mathrm{E}$ (Fig. 1). The majority of collecting places was located at eastern southern foothill region and at low altitude. The habitats were mainly different kinds of steppes, but also taiga forests, alpine meadows and mountain tundra. The lowest locality was in the valley of the river Ilek, Novoiletzk (100 m a.s.l.) and

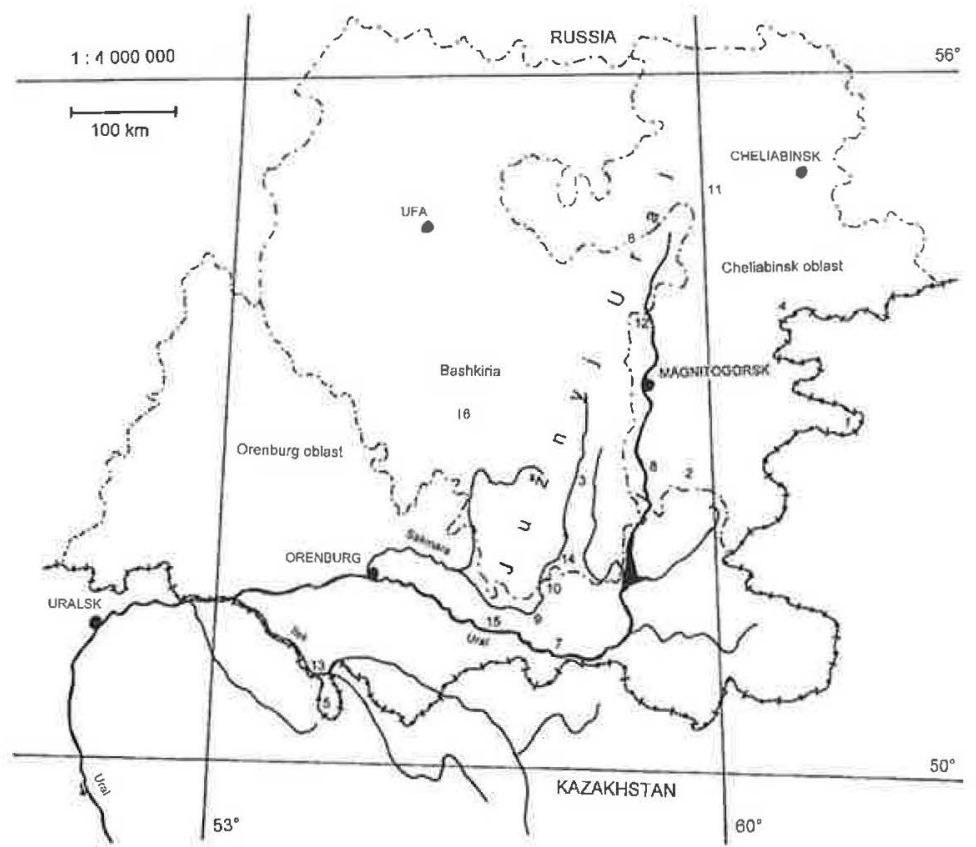

Fig. 1. Map of southern Ural region with collecting localities. 1. Ajat river; 2. Arkaim; 3. Bajmak; 4. Berlin; 5. Chalk Hills; 6. Iremel; 7. Kidriasovo; 8. Kizilskoye; 9. Kuvandyk; 10. Kuvandyk 2; 11. Miass; 12. Moskovo; 13. Burannoe, Novoiletzk; 14. Sakmara river; 15. Verbljushka; 16. Zirgan. 
the highest one the Iremel Mountain ( $1580 \mathrm{~m}$ a.s.l.). Most localities were lying at an elevation of $200-450 \mathrm{~m}$.

The present article is based on the material collected during 1996-1999 in 5 different expeditions. The dates, visited areas and collectors in each of the trips are as follow:

- 1: 13.-29.VI.1996; Cheliabinsk oblast, Bashkiria; K. Nupponen, J.-P. Kaitila, J. Junnilainen, M. Ahola.

- 2: 26.VI.-16.VII.1997; Cheliabinsk oblast; K. Nupponen, J.-P. Kaitila, J. Junnilainen, M. Ahola.

- 3: 25.V.-22.VI.1998; Orenburg oblast, Cheliabinsk oblast, Bashkiria; K. Nupponen, T. Nupponen, J. Junnilainen.

- 4: 11.-31.VII.1998; Orenburg oblast, Cheliabinsk oblast, Bashkiria; K. Nupponen.

- 5: 10.-30.VI.1999; Orenburg oblast, Cheliabinsk oblast, Bashkiria; K. Nupponen, T. Nupponen.

The material, altogether over 1300 specimens of scythridids, is mostly deposited in the private collections of the observers. Some duplicates, including several paratypes, are in the collections of Bengt $\AA$. Bengtsson and Zoological Museum, University of Helsinki. In addition to the material collected, at least another 1300 scythridid specimens were observed but not collected because they were easily determined in the field, especially in the case of mass occurrence of certain species. The overwhelming majority of the material was collected by sweeping and netting at daylight. A few specimens were also collected by artificial light.

The material has been examined by Kari Nupponen and Bengt $\AA$. Bengtsson. To avoid multi-authorship, the new species are described by varying combination of authors. In the cases of two authors, the second author has collected a noteworthy part of specimens or the first specimen of the new taxon. The type specimens can be loaned by request through the Zoological Museum, University of Helsinki or straight from the owners.

The collecting localities are mentioned below. Brief variants of locality names are given in uppercase letters before each locality and used later in the species list. The number given to each of the localities is connected with that on the map (Fig. 1).

- 1, AJAT RIVER: Cheliabinsk oblast, 530'N 6206'E, $200 \mathrm{~m}$, Ajat river near Nikolaevka village. A rocky hill in a riverbank, surrounded by a moist place on a riverside and a large Artemisia steppe. 03.-05.VII.1997, 24.-25.VII.1998.

-2, ARKAIM: Cheliabinsk oblast, $52^{\circ} 39^{\prime} \mathrm{N} 59^{\circ} 34^{\prime} \mathrm{E}, 350$ $\mathrm{m}$, Arkaim reserve near Amurskii village. A large reserve with different kinds of steppe habitats. 14.-19.VI.1996, 06.-
10.VII.1997, 22.-23.VII.1998, 15.-16.VI.1999.

- 3, BAJMAK: Bashkiria, $52^{\circ} 40^{\prime} \mathrm{N} 58^{\circ} 34^{\prime} \mathrm{E}, 450 \mathrm{~m}$, Bajmak $15 \mathrm{~km}$ E. Open foothill steppe locality. 17.18.VI.1998.

-4, BERLIN: Cheliabinsk oblast, $53^{\circ} 59^{\prime} \mathrm{N} 61^{\circ} 12^{\prime} \mathrm{E}, 250$ $\mathrm{m}$, Troizkii reserve near Berlin village. A small, mainly grassland steppe surrounded by a bog and young forest. 30.VI. 02.VII.1997.

- 13, BURANNOE: Orenburg oblast, 505' N 54 $25^{\prime} \mathrm{E}$, $100 \mathrm{~m}$, near Burannoe village, Ilek river valley. Lowland Artemisia steppes, wet meadows and wetlands. 20.21.VI.1999.

- 5, CHALK HILLS (Fig. 2): Orenburg oblast, 5040$45^{\prime} \mathrm{N} 54^{\circ} 26-28^{\prime} \mathrm{E}, 170-230 \mathrm{~m}$, Pokrovka village $20 \mathrm{~km} \mathrm{~S}$, Schibendy valley. A dry, open, lowland Artemisia austriaca steppe with wet meadows along the small riverside. Whitish limestone rocks surround the flat valley, the vegetation being luxurious in northern slopes and very sparse in southern slopes. 03.-07.VI.1998, 17.-18.VII.1998, 21.-24.VI.1999.

- 6, IREMEL: Cheliabinsk oblast, $54^{\circ} 31-35^{\prime} \mathrm{N} 58^{\circ} 49-$ 54'E, 900-1580 m, Iremel Mountain reserve. Taiga forest between $800-1300 \mathrm{~m}$, alpine meadows at $1300-1400 \mathrm{~m}$ and mountain tundra at the highest elevation over $1400 \mathrm{~m}$. 24.27.VI.1996, 11.-14.VII.1997, 25.-28.VI.1999.

- 7, KIDRIASOVO: Orenburg oblast, $51^{\circ} 13^{\prime} \mathrm{N} 57^{\circ} 37^{\prime} \mathrm{E}$, $350 \mathrm{~m}$, Mednogorsk $20 \mathrm{~km}$ S, near Kidriasovo village. Open, partly gravelly foothill steppe with plenty of Caragana bushes in lower parts of the slopes and wet meadows between the the hills. 28.-30.V.1998, 16.VI.1999.

- 8, KIZILSKOYE: Cheliabinsk oblast, 52³9'N 5900'E, $300 \mathrm{~m}$, Kizilskoye $15 \mathrm{~km} \mathrm{~S}$, near Ural river. Dry, open Artemisia austriaca - Stipa steppe with rocky hills. 27.28.V.1998.

9, KUVANDYK: Orenburg oblast, 51 $26^{\prime} \mathrm{N} 57^{\circ} 26^{\prime} \mathrm{E}$, $250 \mathrm{~m}$, Kuvandyk $12 \mathrm{~km}$ SE. A foothill region with different kinds of steppes and old Quercus - Populus - Betula forests on the top of the hills.13.-16.VI.1998, 19.-21.VII.1998.

- 10, KUVANDYK 2: Orenburg oblast, $51^{\circ} 37^{\prime}$ N $57^{\circ} 34^{\prime} \mathrm{E}$, $300 \mathrm{~m}$, Kuvandyk $30 \mathrm{~km}$ NE. Rocky hills and meadows, at the slopes some blackish coloured, hot, gravelly spots with sparse vegetation. 16.-17.VI.1998.

- 11, MIASS: Cheliabinsk oblast, $55^{\circ} 01^{\prime} \mathrm{N} 60^{\circ} 06^{\prime} \mathrm{E}, 350$ $\mathrm{m}$, Miass, Ilmen State reserve. Forest steppes and old conifer forests. 13.VI.1996, 28.-29.VI.1996, 26.-29.VI.1997, 15.16.VII.1997, 25.-26.V.1998, 19.-20.VI.1998, 29.VI.1999.

- 12, MOSKOVO: Cheliabinsk oblast, $53^{\circ} 57^{\prime} \mathrm{N} 59^{\circ} 03^{\prime} \mathrm{E}$, $650 \mathrm{~m}$, near Moskovo village. Open, rocky foothill region

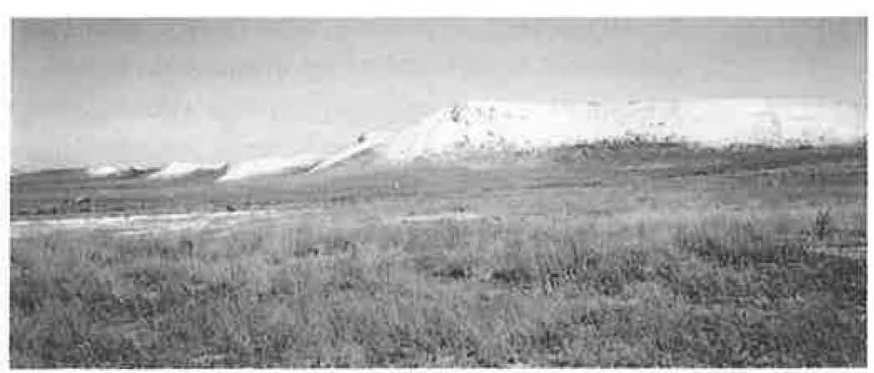

Fig. 2. Chalk Hills. The habitat of Scythris acipenserella sp. n., S. albisaxella sp. n., S. brunneofasciella sp. n., S. olschwangi sp. n., S. perlucidella sp. n., S. remexella $\mathrm{sp}$. n. and many other scythridids mentioned in the present article. 


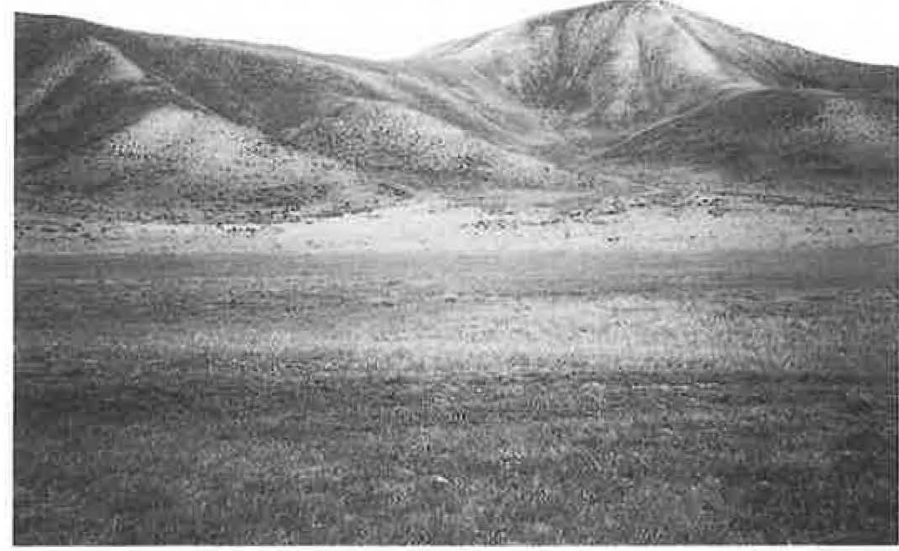

Fig. 3. Verbljushka. The habitat of Scythris elenae sp. n., S. eversmannisp. n., S. perlucidella sp. n., S. setiella (Z.) and S. sublaminella sp. $\mathrm{n}$. with different kinds of steppes and wet meadows along the riverside. 22.-23.VI.1996, 10.-11.VII.1997, 26.V.1998, 18.VI. 1998, 11.-13.VII.1998.

- 13, NOVOILETZK: Orenburg oblast, $50^{\circ} 59^{\prime} \mathrm{N} 54^{\circ} 17$ $22^{\prime} \mathrm{E}, 100 \mathrm{~m}$, Novoiletzk $8 \mathrm{~km}$ E, Ilek river valley. Sand dune region with few Artemisia steppe spots, wet meadows and wetlands. 08.-09.VI.1998.

- 14, SAKMARA RIVER: Bashkiria, 51 ${ }^{\circ} 54^{\prime} \mathrm{N} 57^{\circ} 43^{\prime} \mathrm{E}$, $450 \mathrm{~m}$, Sakmara river near Jantyshevo village. Forest steppes, meadows and mixed forests. 20.-21.VI.1996.

- 15, VERBLJUSHKA (Fig. 3): Orenburg oblast, 51²3'N $56^{\circ} 49^{\prime} \mathrm{E}, 130-340 \mathrm{~m}$, Donskoje village $6 \mathrm{~km}$ W, Mount Verbljushka. A $200 \mathrm{~m}$ high hill in the Ural River bank at the southern corner of the foothill region. The southern slope is extremely hot with more or less sparse vegetation. Artemisia austriaca steppe is present in the western slope and quite a luxuriant, rich flora in the northern slope. There are wet meadows and deciduous forest between the hill and the river. 30 .V.02.VI.1998, 10.-12.VI.1998, 14.-16.VII.1998, 17.-19.VI. 1999.

16, ZIRGAN: Bashkiria, 5312'N 56º0'E, 400 m, near Zirgan village. Forest steppes. 24.VI.1999.

\section{List of scythridid species}

The species are presented in alphabetic order as the family Scythrididae has not been revised and the relationships within the family are not fully understood. The known distribution for each species is given, as well as further notes on some poorly known species.

\section{Scythris acipenserella K. Nupponen \& T. Nup- ponen sp. $n$.}

Type material. Holotype: of (Fig. 4): Russia, southern Urals, $50^{\circ} 45^{\prime} \mathrm{N} 54^{\circ} 28^{\prime} \mathrm{E}, 170 \mathrm{~m}$, Orenburg oblast, Pokrovka village $20 \mathrm{~km} \mathrm{~S}$, Schibendy valley, 22.VI.1999, leg. T. \& K.
Nupponen. In coll. T. \& K. Nupponen. Paratypes (40 ơ $\sigma^{\star}$, 8 우): Same data as holotype, except for dates: $1 \sigma^{\circ}$ 21.VI.1999; 31 đ $^{\star} 0^{\star}, 6$ 우 우 22.VI.1999; 8 o $^{\circ}$, 2우 우 23.VI.1999. Genitalia slides: K. Nupponen prep. no. $1 /$ 17.X.1999, 2/17.X.1999, 1/23.X.1999; 2 further genitalia preparations preserved in glycerol. Paratypes in the collections of T. \& K. Nupponen, Bengt $\AA$. Bengtsson and Zoological Museum, University of Helsinki.

Additional material. $10^{*}$ Spain, prov. Granada, Alpujarra, 17.-23.V.1997, leg. L. Sippola. In coll. Sippola.

Diagnosis. Habitually S. acipenserella sp. n. is very similar to $S$. remexella sp. n. (see below). Forewing of acipenserella darker, pale markings more distinct and a dark spot at cell end more indistinct. Male genitalia with bunch of long bristles reminding of $S$. sitarcha Meyrick, 1918 and $S$. platypyga Staudinger, 1880 , but differ from both in many other characters, like laterally fused, rectangular valvae and shape of lateral processes in tegumen.

Description. Wingspan 6-7.5 mm. Head, antenna, collar, tegula and thorax brown. Labial palp, haustellum and neck tuft pale greyish brown; labial palp short, less than $1.5 \mathrm{x}$ diameter of eye. Legs pale fuscous, hind legs paler. Abdomen dorsally fuscous; ventrally greyish beige, in male basally darker. Forewing dark brown with scattered paler scales occurring in numbers in apical area and more or less sparsely elsewhere; in fold greyish beige streak from base to tornus, cut by dark brown spot at midwing; another, larger dark brown spot at cell end; tornal and costal spots greyish beige, more or less distinct. Hindwing fuscous.

Male genitalia (Fig. 5, Fig. 6). Uncus reduced. Socii with long bristles. Gnathos robust, round- 
ish, ventrally concave, distally slightly tapered and cut-off. Tegumen large, anteriorly with two thick, distally rounded lateral processes and two triangular, posterolateral processes. Aedeagus short and thick, distally with tapered, pointed extension and longer thick, blunt process. Valvae small, rectangular, laterally fused. Sternum VIII small, crescent-shaped, anterior margin slightly concave. Tergum VIII wide, terminally bilobed; lobes hornlike, bent and pointed processes; from base of lobes backward two long, narrow, apically slightly curved formations; laterally triangularly extended, extensions medially with triangular flaps.

Female genitalia (Fig. 7). Sterigma long, tubular, basally slightly widened; tip sclerotized, bent and tapered; cephalic portion straight, more or less membranous and wrinkled. Sternum VII quadrangular, posterior corners blunt; medioposteriorly furnished with weakly sclerotized, roundish, pouch-like formation. Sternum VIII basally and laterally slightly wrinkled. Apophyses posteriores long and slender. Apophyses anteriores $0.4 \mathrm{x}$ length of apophyses posteriores.

Bionomy. The specimens were collected in the second part of June. The habitat was a large Artemisia austriaca steppe.

Distribution. Russia (S-Ural), Spain.

Etymology. The species name refers to the ground colour of the forewing, shining at daylight in equal dark tone as black caviar produced by the Caspian Sea sturgeon (Acipenser stellatus Pallas, 1771).

Remarks. In addition to the type series, one further specimen was surprisingly found among the material collected from southern Spain. This male specimen is darker with more indistinct pale markings on the forewings than the specimens collected from the southern Urals. However, the male genitalia are identical. The habitual difference may due to the extremely pale colour of the soil in Chalk Hills, as the majority of the moth specimens are paler coloured in that locality than those in normal habitats. The same kind of bicentric distribution exists in several species occurring in Chalk Hills, for example Asalebria pseudoflorella (A. Schmidt, 1934) (K. Nupponen, unpublished). Because of habitual difference and a long distance between the type locality and southern Spain, the spanish specimen is not included in the type material.

The combination of characters in the male and female genitalia does not coincide with any known species-group.

\section{Scythris aegrella K. Nupponen \& Junnilainen sp. $n$.}

Type inaterial. Holotype: $\sigma^{*}$ (Fig. 8): Russia, southern Urals, $50^{\circ} 59^{\prime} \mathrm{N} 54^{\circ} 17-22^{\prime} \mathrm{E}, 100 \mathrm{~m}$, Orenburg oblast, Novoiletzk 8 km E, 08.VI.1998, leg. J. Junnilainen. Genitalia slide: K. Nupponen prep. no. 3/14.II.1999. In coll. J. Junnilainen. Paratypes (9 $90^{\circ}, 1$ \%): Russia, southern Urals, $50^{\circ} 58^{\prime} \mathrm{N} 54^{\circ} 25^{\prime} \mathrm{E}$, Orenburg oblast, near Burannoe village, $3 \sigma^{*} \sigma^{*}$ 20.VI.1999, $6 \sigma^{*} \sigma^{*}, 1$ ㅇ 21.VI.1999, leg. T. \& K. Nupponen. Genitalia slide: K. Nupponen prep. no. 1/18.X.1999 (क); 1 further genitalia preparation preserved in glycerol. Paratypes in the collections of T. \& K. Nupponen and Bengt Å. Bengtsson.

Diagnosis. Externally $S$. aegrella sp. n. may be confused with many medium-sized, dark scythridids. Indistinct black streaks surrounding fold on the forewing may help to identify the moth. Male genitalia of the new taxon are typical of the pascuella group, the main distinguishing characters being a broad, triangular flap and apico-lateral extension in valva.

Description. Wingspan 12-13.5 mm. Head, antenna, collar, tegula and thorax purplish olive brown. Haustellum and neck tuft pale brown. Labial palp dark brown, segment I and upper surface of segment II covered with pale scales. Foreand midlegs brown, glossy, more or less mixed with pale scales; hindlegs pale greyish brown. Abdomen dorsally olive fuscous, ventrally pale yellowish grey. Forewing dark olive brown, slightly purplish; paler scales in fold from base to midwing and a few ones near dorsum; on both sides of fold indistinct, more or less breaking black streak from 0.2 to cell end. Hindwing brown.

Male genitalia (Fig. 9, Fig. 10). Uncus bifurcate prong, arms straight. Gnathos long, terminal half tapered, tip bent and pointed. Aedeagus 3/4 of valva length, almost straight, terminally tapered. Valva longish, curved, apically widened and cut off; ventrally at 0.4 from base broad, triangular flap; in central part of valva longitudinal fold from base to 0.7 . Vinculum without posterior incurvation. Sternum VIII subpentagonal, posterior extension long with bifurcate apex. Tergum VIII subtrapezoid, posterior margin straight. 
Female genitalia (Fig. 11). Sterigma subpentagonal, posterior margin medially incised; sclerotization extended anteriorly. Ostium rimmed. Antrum weakly sclerotized. Sternum VII subquadrangular, mid-posteriorly furnished with semicircular process; posterior margin convex with very small medial incision; anterior margin slightly concave. Apophyses posteriores long and slender. Apophyses anteriores $0.5 \mathrm{x}$ length of apophyses posteriores.

Bionomy. The specimens were collected in the second third of June. The habitats were lowland Artemisia steppes in the zone where the steppe changes to a wet meadow.

Distribution. Russia (S-Ural). The taxon is known from Orenburg oblast in the southern Ural region. To date, there are two known places for the species located close to each other in the valley of the river Ilek.

Etymology. Lat. aegra = difficult. The name refers to the history of the discovery of the species. We were searching for a sand dune region in Novoiletzk in the evening. While driving along a steppe, the habitat suddenly changed to a wetland and our car partly sunk into a soft ground. We were forced to wait there one day for help. Despite difficulties, we quickly jumped out from the car for collecting, and later found the first specimen of $S$. aegrella among that material.

Remark. S. aegrella belongs to the pascuella species-group.

\section{Scythris albisaxella K. Nupponen \& T. Nuppo- nen sp. $\mathbf{n}$.}

Type material. Holotype: $\sigma^{7}$ (Fig. 12): Russia, southern Urals, $50^{\circ} 45^{\prime} \mathrm{N} 54^{\circ} 28^{\prime} \mathrm{E}, 170 \mathrm{~m}$, Orenburg oblast, Pokrovka village $20 \mathrm{~km} \mathrm{~S}$, Schibendy valley, 07.VI.1998, leg. T. \& K. Nupponen. In coll. T. \& K. Nupponen. Paratypes (51 $\sigma^{*} \sigma^{*}$, 20 ㅇ ₹ ): Same data as holotype, except for dates: $2 \sigma^{*} \sigma^{*}$

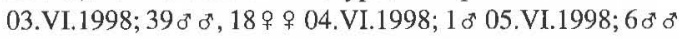
07.VI.1998; $3 \sigma^{\star} \sigma^{*}, 2$ 우우 22.VI.1999. 1 우 Same locality as holotype but 03.-07.VI.1998, leg. J. Junnilainen. Genitalia slides: K. Nupponen prep. no. 4/15.XI.1998, 1/03.I.1999; 2 further genitalia preparations preserved in glycerol. Paratypes in the collections of T. \& K. Nupponen, Bengt $\AA$. Bengtsson, $J$. Junnilainen and Zoological Museum, University of Helsinki.

Diagnosis. May be confused with many small, dark scythridids, for example $S$. gozmanyi Passerin d'Entrèves and $S$. arkaimensis sp. n. (see below). Brown (not blackish) ground colour and disconnected white streak of forewing are good distinguishing marks for the species. The genitalia separate $S$. albisaxella sp. n. from other known scythridids (see Remarks).

Description. Wingspan 7.5-8.5 mm. Head, antenna, collar, tegula and thorax brown. Neck tuft and haustellum pale brown. Labial palp pale brown, terminally darker. Abdomen dorsally fuscous, ventrally pale yellowish brown. Legs yellowish brown. Forewing brown; disconnected white streak in fold from base to cell end, cut by 3 moderately indistinct blackish brown spots at $0.3,0.5$ and 0.8 , such very indistinct spots being present also above tornus and at apex; apical area mixed with more or less numerous whitish grey scales. Hindwing fuscous.

Male genitalia (Fig. 13, Fig. 14). Tegumen extended left-posteriorly. Uncus left weighted, short, rectangular; strong terminal sclerotization shaped as molar tooth. Gnathos moderately long, tapered, terminally strongly sclerotized. Aedeagus thick and short, terminally curved and tapered. Valvae basally fused, then with short, narrow shaft; apical 3/4 large, spatular, setose process; ventral margin almost straight, dorsal margin convex, apex rounded. Sternum VIII rectangular, $3 \mathrm{x}$ as wide as high. Tergum VIII subtriangular, with deep apical cleavage; anterior margin concave; lateral processes long, bent, asymmetrical, larger one with strongly sclerotized apex.

Female genitalia (Fig. 15). Sterigma triangular, tip strongly sclerotized, distally blunt; basal corners extended, pointed. Sternum VII subrectangular, posteriorly slightly extended with Ushaped medial incision and small labiate sclerotization at 'bottom' of incision. Apophyses anteriores $1 / 3 x$ length of apophyses posteriores.

Bionomy. The specimens were collected in the beginning of June. The moth was active in the afternoon sunshine, although the first two specimens were caught by artificial light. The habitat was a wide Artemisia austriaca steppe.

Distribution. Russia (S-Ural). Only known from the type locality.

Etymology. Lat. albus = white; saxus = rock. From the habitat; Schibendy valley is bordered by extremely calcareous, white and rocky slopes, called Chalk Hills by the local people.

Remarks. There are several eastern scythrid- 
ids with the genitalia morphology similar to albisaxella, typical features being spatular and setose, basally fused valvae and asymmetrical, strongly sclerotized gnathos in the male genitalia. Such features are typical of e.g. S. arkaimensis sp. n. (see below) and of the recently described S. terekholensis Bengtsson, 1997. S. albisaxella is placed in this species group. The female genitalia are close to those of $S$. kullbergi Bengtsson, 1997 but differing from that in details: in albisaxella the sterigma is narrower with distally broader sclerotized tip and sternum VII less elongate with smaller labiate sclerotization and incised posterior margin.

\section{Scythris arkaimensis Bengtsson sp. n.}

Type material. Holotype: ${ }^{\star}$ (Fig. 16): Russia, S-Ural, Cheliabinsk oblast, $52^{\circ} 39^{\prime} \mathrm{N} 59^{\circ} 34^{\prime} \mathrm{E}, 350 \mathrm{~m}$, Arkaim reserve near Amurskii village, 15.VI.1996, leg. K. Nupponen, J.-P. Kaitila, J. Junnilainen \& M. Ahola. Genitalia slide: B ̊B 714X. In coll. T. \& K. Nupponen.

Diagnosis. Similar to a small S. picaepennis (Haworth, 1828) but genitalia quite different.

Description. Wingspan ca $9 \mathrm{~mm}$. Head dark brownish. Basal joint of labial palp whitish, second joint fuscous with plenty of whitish scales, twice as long as diameter of eye, terminal joint short, fuscous. Scape and flagellum of antenna [broken near scape] brownish. Collar laterally dirty whitish. Tegula and thorax dark fuscous. Forewing with dark fuscous coloration, mixed in with several paler scales, especially in apical part. Hindwing fuscous, darker at tip. Legs brownish beige with some scattered whitish scales but foreleg femur and hindleg tibia whitish. Male abdomen fuscous dorsally, beige with dirty whitish scales ventrally.

Male genitalia (Fig. 17). Uncus bifid, indentation U-shaped. Valva blade-shaped, inner margin straight, outer curved, near base constricted. Two asymmetrical processes basally on valva, left one with very pointed elbow and rounded, minutely furrowed tip, right one with rounded elbow, tip rounded and rough. Sternum VIII rectangular plate (see also Remarks).

Female genitalia. Unknown.

Distribution. Russia (S-Ural). Only known from the type locality.
Bionomy. Unknown. Imago appears in June in steppe habitat. locality.

Etymology. The species-name refers to the type

Remarks. The genitalia is partly attacked by noxious animals. Aedeagus and tergum VIII are eaten up. Gnathos is also missing in the genitalia, but possibly it is in fact reduced. However, there remains enough characteristic details (valva, uncus) in the genitalia to separate the new taxon from other known species. For the moment it is difficult to assign the taxon to a known species-group. Fresh specimens including females may solve the problem.

\section{Scythris bengtssoni Patocka \& Liska, 1989}

Arkaim 16.VI.1996, 08.-09.VII.1997, 22.VII. 1998, 15.VI.1999; Moskovo 19.VI.1998. A total of 11 exx.

Distribution. Eastern central Europe (Austria, Czech Republic, Hungary, Slovakia, Switzerland).

Remark. These records extend the known distribution of the species over $2000 \mathrm{~km}$ to the east. New to Russia.

\section{Scythris bifissella (Hofmann, 1889)}

Ajat river 03.-05.VII.1997; Arkaim 14.-19.VI. 1996, 07.10.VII.1997; Berlin 30.VI.-02.VII. 1997; Burannoe 20.VI.1999; Chalk Hills 04.-07.VI.1998, 22.-23.VI.1999; Kidriasovo 28.-29.V. 1998, 16.VI.1999; Kizilskoye 28.V.1998; Kuvandyk 16.VI.1998; Kuvandyk 2 16.17.VI.1998; Moskovo 26.-27.V.1998, 18.-19.VI.1998, 12.VII. 1998. Common.

Distribution. C Europe, Russia (Baikal region, Altai Mountains).

\section{Scythris braschiella (Hofmann, 1898)}

Moskovo 11.VII.1998. 1 ㅇ․

Distribution. Germany, Greece, Turkey, Poland (Baran 1996).

Remarks. This record extends the known distribution considerably to the east. New to Russia.

Scythris brunneofasciella K. Nupponen \& Junnilainen sp. $n$.

Type material. Holotype: 우 (Fig. 18): Russia, southem Urals, $50^{\circ} 40^{\prime} \mathrm{N} 54^{\circ} 26^{\prime} \mathrm{E}, 220 \mathrm{~m}$, Orenburg oblast, Pokrovka vil- 
lage $20 \mathrm{~km} \mathrm{~S}$, Schibendy valley, 03.-07.VI.1998, leg. J. Junnilainen. Genitalia slide: K. Nupponen prep. nо. 2/14.II.1999. In coll. J. Junnilainen.

Diagnosis. S. brunneofasciella sp. $\mathrm{n}$. is easy to separate from other known scythridids by the broad, brown fascia of the forewing.

Description. Wingspan $13.5 \mathrm{~mm}$. Head, antenna, haustellum and labial palp brown. Collar, neck tuft and thorax blackish brown, slightly purplish, mixed with a few brown scales. Legs blackish brown with following whitish brown ringshaped markings: terminal $1 / 4$ of femur; two broad rings at 0.5 and at end of tibia; two narrow rings at 0.5 and 0.7 of tarsus. Rings in hind legs more distinct. Forewing dark brown, more or less mixed with pale brown scales forming basal dash, distinct broad fascia at 0.7 and narrow terminal fascia; in fold moderately indistinct blackish brown short streak at base, likewise coloured large spot at midwing and another smaller spot at cell end. Hindwing fuscous, margin darker. Fringe in both forewing and hindwing with faint purplish lustre.

Male genitalia. Unknown.

Female genitalia (Fig. 19). Sterigma widely arched, posteriorly shallowly incurved, anterior margin uneven; lateral shanks long, tapered. Sternum VII rectangular; anterior margin with small, roundish medial extension; posterior margin medially concave with separate, flat, rectangular extension, surrounded by two subtriangular extensions. Large membranous pouch connected with posterior margin of sternum VII. Apophyses anteriores $0.5 \mathrm{x}$ length of apophyses posteriores.

Bionomy. The specimen was collected in the beginning of June. The habitat was a hot, southern slope with very sparse vegetation (Fig. 2).

Distribution. Russia (S-Ural). Only recorded from the type locality.

Etymology. The name brunneofasciella alludes to a broad, transversal brown fascia on the forewing of the moth.

Remark. Until the male is found the group to which $S$. brunneofasciella belongs cannot be settled.

\section{Scythris clavella (Zeller, 1855)}

Arkaim 14.-19.VI.1996, 06.-10.VII.1997, 15.-16. VI.1999; Bajmak 17.VI.1998; Berlin 30.VI.-02.VII.1997; Chalk Hills 04.-07.VI.1998, 22.-23. VI.1999; Kidriasovo 28.-30.V.1998, 16.VI. 1999; Kizilskoye 27.-28.V.1998; Kuvandyk 13.-16.VI.
1998; Kuvandyk 2 16.-17.VI.1998; Miass 26.-29. VI.1997; Moskovo 22.-23.VI.1996, 10.-11.VII. 1997, 26.V.1998, 18.VI.1998, 12.VII. 1998; Novoiletzk 8.VI.1998; Sakmara river 20.-21.VI. 1996; Verbljushka 31.V.-02.VI.1998, 10.12.VI. 1998, 17.-19.VI.1999. Widely distributed and often abundant.

Distribution. C and S Europe, east to Altai.

Remarks. In all populations in the area investigated specimens with white markings on forewings were present: a streak in fold and/or a spot at cell end. The ratio between marked and unicoloured specimens was estimated in 4 localities (Chalk Hills, Kuvandyk, Moskovo, Verbljushka) by checking the first 60 specimens in each locality (T. \& K. Nupponen). The portion of marked specimens in populations varied between 25-30 $\%$.

\section{Scythris cretacella K. Nupponen \& T. Nuppo- nen sp. $n$.}

Type material. Holotype: $q$ (Fig. 20): Russia, southern Urals, $50^{\circ} 45^{\prime} \mathrm{N} 54^{\circ} 28^{\prime} \mathrm{E}, 170 \mathrm{~m}$, Orenburg oblast, Pokrovka village $20 \mathrm{~km} \mathrm{~S}$, Schibendy valley, 06.VI.1998, leg. T. \& K. Nupponen. In coll. T. \& K. Nupponen. Genitalia slide: K. Nupponen prep. no. 3/18.X.1999.

Diagnosis. Externally may be confused with several pale scythridids, especially in the canescens group. The female genitalia are rather close to those of $S$. pruinata Falkovitch, 1972 but can be separated from that by broader and shorter sterigma and the sclerotized process in sternum VII.

Description. Wingspan $10 \mathrm{~mm}$. Head, antenna, thorax, collar and tegula pale fuscous. Neck tuft, haustellum and labial palp pale greyish beige. Legs greyish white. Abdomen dorsally beige, ventrally greyish white. Forewing pale fuscous, paler at costa; indistinct blackish brown streak in fold from base to midwing and dash of same colour at cell end; dorsal margin of fold and apical half of wing with scattered dirty white scales; fringe beige. Hindwing basally whitish, apically pale fuscous.

Male genitalia. Unknown.

Female genitalia (Fig. 21). Sterigma rectangular, mid-anteriorly around ostium roundish area without sclerotization. Sternum VII subquadrangular; anterior margin medially incurved; posterior margin medially with V-shaped incurvation and small, roundish, weakly sclerotized process. Apophyses posteriores long and slender. Apophy- 
ses anteriores $3 / 4 x$ length of apophyses posteriores.

Bionomy. The specimen was collected in the beginning of June. The habitat was a wide Artemisia austriaca steppe.

Distribution. Russia (S-Ural). Only known from the type locality.

Etymology. Lat. cretaceus $=$ pertaining to chalk. From the habitat; the taxon was found on Chalk Hills (see above: the etymology of albisaxella).

Remark. S. cretacella may belongs to the canescens species-group, but this can not be confirmed until the male is found.

\section{Scythris disparella (Tengström, 1848)}

Berlin 02.VII.1997. 5 exx.

Distribution. Europe, Russia.

\section{Scythris elenae K. Nupponen sp. n.}

Type material. Holotype: o (Fig. 22): Russia, southern Urals, $51^{\circ} 23^{\prime} \mathrm{N} 56^{\circ} 49^{\prime} \mathrm{E}, 300 \mathrm{~m}$, Orenburg oblast, Donskoje village $6 \mathrm{~km} \mathrm{W,} \mathrm{Mount} \mathrm{Verbljushka,} \mathrm{02.VI.1998,} \mathrm{leg.} \mathrm{T.} \mathrm{\&} \mathrm{K.}$ Nupponen. Genitalia slide: K. Nupponen prep. no. 3/ 14.XI.1998. In coll. T. \& K. Nupponen.

Diagnosis. Habitually most resembling $S$. braschiella (Hofmann, 1898) and S. bubaniae Walsingham, 1907 but differing from those by broader wings and more robust appearance. The genitalia separate $S$. elenae sp. n. from other known taxa (see Remarks).

Description. Wingspan $8.5 \mathrm{~mm}$. Head, antenna, haustellum, labial palp, collar, tegula, neck tuft and thorax dark brown. Abdomen and legs dark fuscous. Forewing dark brown; ochreous brown spot in fold at $1 / 3$, and another spot of same colour at cell end reaching tornus. Both spots are surrounded with blackish brown speckles in fold. Hindwing fuscous, faintly glossy.

Male genitalia (Fig. 23, Fig. 24). Uncus roundish, extended, distally deeply incised; in distal part of lateral margins sclerotized bulge. Gnathos base subrectangular, furrowed plate; distal part long, bent, tapered and pointed. Aedeagus long and slender, bent, tapered at middle. Valva of constant width, apical half slightly bent inwards and setose, tip ending pointed at ventral margin. Ster- num VIII pentagonal, flat with rounded corners. Tergum VIII rectangular, $2.5 \mathrm{x}$ as wide as high, posterior margin convex.

Female genitalia. Unknown.

Bionomy. The holotype was caught in the beginning of June while flying over the low vegetation in sunshine at 6 p.m. The habitat was a steep, extremely hot and dry steppe slope with Artemisia austriaca as a dominant plant.

Distribution. Russia (S-Ural). Only known from the type locality.

Etymology. I dedicate this species to my wife Elena.

Remarks. The combination of characters does not coincide with any known species-group. Externally $S$. elenae is close to the laminella group, but uncus-gnathos complex in the male genitalia is well developed and aedeagus very long. Setose valvae and long, slightly bent aedeagus fit in with the knochella group. Uncus is shaped like an illdeveloped horseshoe as in the schleichiella group, with remains of lateral processes typical for the cicadella group. However, a long gnathos, sternum VIII without medioposterior incision, small size and external appearance of the taxon are strange for these groups. S. elenae may form its own group close to the knochella and cicadella groups but this cannot be confirmed until the female is found.

\section{Scythris emichi (Anker, 1870)}

Berlin 02.VII.1997; Chalk Hills 18.VII.1998, 23.VI.1999. A total of 8 exx.

Distribution. Hungary, Latvia.

Remarks. These records extend the known distribution over $2000 \mathrm{~km}$ to the east. Probably widely distributed in central parts of the Palaearctic region. New to Russia.

\section{Scythris ericetella (Heinemann, 1872)}

Moskovo 22.-23.VI.1996, 10.VII.1997, 11.VII. 1998. 14 exx. Distribution. C and W Europe.

Remarks. Most specimens were caught by artificial light. New to Russia. 


\section{Scythris eversmanni K. Nupponen \& T. Nuppo- nen sp. $n$.}

Type material. Holotype: ${ }^{*}$ (Fig. 25): Russia, southern Urals, $51^{\circ} 23^{\prime} \mathrm{N} 56^{\circ} 49^{\prime} \mathrm{E}, 250 \mathrm{~m}$, Orenburg oblast, Donskoje village $6 \mathrm{~km} \mathrm{W,} \mathrm{Mount} \mathrm{Verbljushka,} \mathrm{01.VI.1998,} \mathrm{leg.} \mathrm{T.} \mathrm{\&} \mathrm{K.}$ Nupponen. In coll. T. \& K. Nupponen. Paratypes (12 $\sigma^{\circ}$, 3 ㅇ f ) : $1 \sigma^{*}$ Same data as holotype but 02.VI.1998. 1 i Same locality as holotype but 30.V.-02.VI.1998, leg. J. Junnilainen. $50^{\circ} \sigma^{\circ}$ Russia, southern Urals, $51^{\circ} 13^{\prime} \mathrm{N} 57^{\circ} 37^{\prime} \mathrm{E}, 350 \mathrm{~m}$, Orenburg oblast, Mednogorsk $20 \mathrm{~km}$ S, near Kidriasovo village, 29.V.1998, leg. T. \& K. Nupponen. $40^{\star \top} 0^{\star}, 1$ \& Same locality as previous paratype but 28.-29.V.1998, leg. J. Junnilainen. $2 \sigma^{\prime} \sigma^{\circ}$ Russia, southern Urals, $52^{\circ} 39^{\prime} \mathrm{N} 59^{\circ} 00^{\prime} \mathrm{E}, 300$ $\mathrm{m}$, Cheliabinsk oblast, Kizilskoye $15 \mathrm{~km} \mathrm{~S}$, near Ural river, 28.V.1998, leg. T. \& K. Nupponen. 1 \% Russia, S-Ural, Cheliabinsk oblast, $52^{\circ} 39^{\prime} \mathrm{N} 59^{\circ} 34^{\prime} \mathrm{E}, 350 \mathrm{~m}$, Arkaim reserve near Amurskii village, 16.VI.1996, leg. K. Nupponen, J.-P. Kaitila, J. Junnilainen \& M. Ahola. Genitalia slides: K. Nupponen prep. no. 3/15.XI.1998, 1/14.II.1999; B $\AA$ B 716X; 1 further genitalia preparation preserved in glycerol. Paratypes in the collections of T. \& K. Nupponen, J. Junnilainen and Bengt $\AA$. Bengtsson.

Diagnosis. Externally $S$. eversmanni sp. n. may be confused with several other dark scythridids, for example $S$. bifissella (Hofmann, 1889) and $S$. sublaminella sp. $\mathrm{n}$. (see below). The pale scales on forewing are more whitish in eversmanni, but they are easily chafed away. The genitalia separate eversmanni from other known species (see Remarks).

Description. Wingspan 10.5-11 mm. Head, antenna, collar, tegula and thorax dark brown, glossy. Neck tuft pale brown. Haustellum dark brown, mixed with paler scales. Labial palp: segment I, basal half of segment II and upper surface of segment III pale brown, otherwise dark brown. Forelegs and midlegs dark brown, hindlegs paler. Abdomen dark brown, glossy, ventrally mixed with paler scales, terminal scales whitish brown. Forewing blackish brown with purplish lustre; in fold greyish white scales forming streak from base to tornus; such scales occur all over wing, sparsely at basal area but in numbers in apical half; small, indistinct black spot at cell end; fringe brown, paler than forewing. Hindwing pale fuscous.

Male genitalia (Fig. 26, Fig. 27). Uncus bilobed, both lobes cup-shaped, terminally with two ridge-like extensions. Base of gnathos semicircular band, posterior part long and bent, tip hooked. Valva setose, short, cup-shaped. Aedeagus straight and thick, narrowed at 1/3 from base, posteriorly enlarged and rounded with point at tip. Tegumen extended posterolaterally, ending in square angle at each side. Tergum VIII subrectangular with following extensions: terminal process thick, tapered, distally bilobed and enlarged, heart-shaped; lateral processes thick, long, curved outward, with large subtriangular flap at $1 / 4$ from base, terminally minutely dentate and tip pointed; anterior corners with rounded extension. Sternum VIII bilobed; distal lobes short, straight, tip rounded; posterior margin medially with $V$-shaped incision, surrounded by two shallow U-shaped incisions; two long, parallel flaps from middle to posterior margin of sternum VIII basally with long, triangular extension; anterior corners with short, thick process; anterior margin with two closed circular processes and deep, U-shaped medial incision.

Female genitalia (Fig. 28). Sterigma at tip conical, then enlarged to huge plate reaching anterior margin of segment VIII, posterior margin triangularly extended. Segment VII narrow, collar-shaped; posterior margin sclerotized, lateral margins extended; ventrally open, posteromedially extended and strongly curved backward. Apophyses posteriores very long and thin. Apophyses anteriores short, moderately thick, slightly bent.

Bionomy. Specimens were collected in the end of May and beginning of June in steppe habitats. All known localities lie in a foothill region north from the River Ural. S. eversmanni seems to prefer hot, gravelly spots with sparse vegetation. Not abundant, all specimens were swept one by one despite perfect weather conditions.

Distribution. Russia (S-Ural). The species is known only from Cheliabinsk and Orenburg oblasts in the southern Ural region, in four different places located close to each other.

Etymology. This species is dedicated to Prof. Eduard Eversmann (1794-1860), a famous German-Russian entomologist who lived in Spasskoye village, very close to the type locality of the new taxon.

Remarks. The combination of characters in the male genitalia of $S$. eversmanni does not coincide well with any known species-group. The pointed, lateral projections on tegumen resemble those of the fallacella group, but uncus-gnathos structure does not fit that group, neither does the external appearance of the moth. The new taxon form its own group close to fallacella. 


\section{Scythris flavilaterella (Fuchs, 1886)}

Berlin 30.VI.-02.VII.1997; Kuvandyk 13.-16.VI. 1998; Kuvandyk 2 16.VI.1998; Bajmak 17.VI. 1998. Common.

Distribution. C and S Europe, Caucasus.

Remarks. Local but often abundant where it occurs. New to Russia.

\section{Scythris flaviventrella (Herrich-Schäffer, 1855)}

Ajat river 03.-05.VII.1997; Arkaim 14.-19.VI. 1996, 07.10.VII.1997; Bajmak 17.VI.1998; Berlin 30.VI.-02.VII.1997; Chalk Hills 04.-07.VI.1998, 22.-23.VI.1999; Kuvandyk 2 16.VI. 1998; Moskovo 10.VII.1997; Verbljushka 31.V. 1998, 10.-12.VI.1998, 18.VI.1999; Zirgan 24.VI. 1999. Common.

Distribution. C and S Europe, Turkey.

Remarks. A widely distributed species, often abundant. New to Russia.

\section{Scythris gozmanyi Passerin d'Entrèves, 1986}

Arkaim 15.-16.VI.1996; Bajmak 17.VI.1998; Berlin 30.VI.02.VII.1997; Burannoe 20.-21.VI. 1999; Chalk Hills 04.07.VI.1998, 21.-23.VI. 1999; Kidriasovo 29.V.1998, 16.VI.1999; Kizilskoye 28.V.1998; Kuvandyk 13.16.VI.1998; Kuvandyk 2 17.VI.1998; Moskovo 11.VII.1997, 19.VI.1998; 12.VII.1998; Verbljushka 02.VI. 1998, 10.12.VI.1998, 17.-19.VI.1999. Common, about 130 exx. collected.

Distribution. Hungary, Poland.

Remarks. There seems to be more variation in external appearance of the moth than in central European populations. The forewing is often more or less mixed with greyish scales and the markings in fold are wider and more distinct in some specimens. The species occurs in dry steppes and is locally abundant. These records extend the known distribution of the species over $2000 \mathrm{~km}$ to the east. New to Russia.

\section{Scythris karinupponeni Bengtsson sp. n.}

Type material. Holotype: $\sigma^{*}$ (Fig. 29): Russia, S-Ural, Cheliabinsk oblast, $53^{\circ} 57^{\prime} \mathrm{N} 59^{\circ} 03^{\prime} \mathrm{E}, 650 \mathrm{~m}$, near Moskovo village, 12.VII.1998, leg. K.Nupponen. Genitalia slide: BÅB 765X. In coll. T. \& K. Nupponen. Paratypes ( $29 \sigma^{\star} \sigma^{\star}, 5 \%$ 5 ): $3 \sigma^{\top}$ S Same data as holotype. Same locality as holotype: $4 \sigma^{\pi} \sigma^{*}$ 09.VII.1997, 4 đ $^{\star}$ o 10.VII.1997, leg. K. Nupponen \& J. Junnilainen. Same locality as holotype: $11 \delta^{\pi} d^{7}, 2 \% q$ 10.VII.1997, leg. J.-P. Kaitila. Russia, S-Ural, Cheliabinsk oblast, 52 $39^{\prime} \mathrm{N} 59^{\circ} 34^{\prime} \mathrm{E}, 350 \mathrm{~m}$, Arkaim reserve near Amurskii village, $2 \sigma^{*}$ 22.VII.1998, $3 \sigma^{*} \sigma^{*}$ 23.VII.1998, leg. K. Nupponen. 1 i Same locality as previous paratypes but 08.VII.1997, leg. J.-P. Kaitila. 1 우 Russia, S-Ural, Cheliab- insk oblast, $53^{\circ} 02^{\prime} \mathrm{N} 62^{\circ} 06^{\prime} \mathrm{E}, 200 \mathrm{~m}$, Ajat river near Nikolaevka village, 04.VII.1997, leg. J.-P. Kaitila. $10^{*}$, 19 Russia, S-Ural, Cheliabinsk oblast, 53⒌' $61^{\circ} 12^{\prime} \mathrm{E}$, $250 \mathrm{~m}$, Troizkii reserve near Berlin village, 30.VI.02.VII.1997, leg. J.-P. Kaitila. 1 o Russia, Magadan oblast, $62^{\circ} 50^{\prime} \mathrm{N} 148^{\circ} 15^{\prime} \mathrm{E}, 750 \mathrm{~m}$, near Susuman, steppe slope/ Larix, 15.VII.1997, leg. Jalava \& Tammaru. Genitalia slides: $\mathrm{B} \AA \mathrm{B} 4221, \mathrm{~B} \AA \mathrm{B} 4222, \mathrm{~B} \AA \mathrm{B} 723 \mathrm{X}$. Paratypes in the collections of T. \& K. Nupponen, J. Junnilainen, J.-P. Kaitila and Bengt $\AA$. Bengtsson except last paratype in coll. Zoological Museum, University of Helsinki.

Additional material. $1 \sigma^{*}$ Same locality as holotype but 18.-19.VI.1998, leg. J. Junnilainen. In coll. J. Junnilainen (see Remarks).

Diagnosis. Habitually most resembling small specimens of S. mikkolai Sinev, 1993 but differing from that by more contrastic coloration of the forewing. The genitalia separate the new taxon from other known scythridids (see Remarks).

Description. Wingspan 7.5-9.0 mm. Head, antenna, tegula and thorax dark fuscous. Collar pale fuscous. Basal joint of labial palp whitish, second and third joint fuscous, with few pale scales. Forewing fuscous, in fold whitish streak, more or less distinct, often also with scattered whitish scales in apical half of wing, especially dorsad fold. Hindwing greyish. Legs fuscous in different shades, with a few pale scales, tarsal joints of hind leg weakly ringed. Abdomen in male fuscous dorsally, slightly paler and less brownish ventrally, in several specimens almost whitish. Anal tuft more or less compressed to genitalia armature and segment VIII. Female abdomen dorsally fuscous, ventrally mottled with dark and beige scales. Papillae anales protruding.

Male genitalia (Fig. 30, Fig. 31). Uncus/gnathos structure transformed to two sclerotized girdles attached ventrally to spherical membrane at top of tegumen, very similar to structure in Scythris mikkolai Sinev, 1993. Valva reminding of head of swan with short beak, in some specimens slightly asymmetrical. Aedeagus rather small, length as half valve, almost straight, tapered with truncated tip. Sternum VIII subtriangular with extended, terminal "handle", anterior deep incision Vshaped. Tergum VIII subrectangular, anteriorly with deep U-shaped incurvation, posteriorly rounded and furnished with stiff long scales, usually remaining after preparation, in situ so closely attached to each other that they can be mistaken for pair of sclerotized plates, usually remaining after preparation. 
Female genitalia (Fig. 32). Sterigma triangular, oblique, surrounded by bent sclerites that are anteriorly widened, membranously recurved and connected with sterigma. Sternum VII wide rectangular plate, medioposteriorly incurved.

Distribution. Known from the south of the Ural Mountains (Cheliabinsk oblast) and from the Magadan district in the eastern Russia.

Bionomy. Unknown. Imago appears in July in forest steppe and in open steppe habitat.

Etymology. I dedicate this species to the collector of most of the type specimens, Kari Nupponen.

Remarks. S. karinupponeni sp. n. is closely related to $S$. mikkolai and is provisionally placed in the heterogeneous pascuella species-group. One male specimen is not included in the type material, because is has not been examined by the author.

\section{Scythris kasyi Hannemann, 1962}

Bajmak 16.-17.VI.1998. $1 \sigma^{\circ}$.

Distribution. Austria, Slovakia.

Remarks. The basal fusion of the plates in sternum VIII is somewhat wider than in Central European specimens. However, the other parts of the male genitalia are identical. This record extends the known distribution over $2000 \mathrm{~km}$ to the east. New to Russia.

\section{Scythris limbella (Fabricius, 1775)}

Sakmara river 20.-21.VI.1996; Kuvandyk 13.-16.VI.1998, 19.-20.VII.1998; Verbljushka 31.V. 1998.

Distribution. Europe to the Altai, C Asia and N America.

Remarks. Common in agricultural biotopes.

\section{Scythris luxatiella K. Nupponen \& Kaitila sp.} n.

Type material. Holotype: o (Fig. 33): Russia, southern Urais, $54^{\circ} 00^{\prime} \mathrm{N} 61^{\circ} 15^{\prime} \mathrm{E}, 250 \mathrm{~m}$, Cheliabinsk oblast, Troizkii Reserve near Berlin village, 30.VI.-02.VII.1997, leg. J.-P. Kaitila. Genitalia slide: K. Nupponen prep. no. 1/14.XI.1998. In coll. J.-P. Kaitila. Paratypes ( 2 q): Same data as holotype. Genitalia slide: K. Nupponen prep. no. 1/02.XII.1998. One genitalia preparation preserved in glycerol. In coll. T. \& $\mathrm{K}$. Nupponen and J. Junnilainen.

Diagnosis. S. luxatiella sp. n. is easily con- fused with many other dark, small scythridids by its external appearance. The moderately long antennae and narrow wing shape with a pale streak in the fold of the forewing may help to identify the moth. Safe determination can only be achieved by examining the genitalia. The shape of valvae and sclerotized gnathos in the strongly asymmetrical male genitalia are characteristic, as well as a sclerotized horn-shaped sterigma in the female genitalia.

Description. Wingspan 8-8.5 mm. Head, antenna, haustellum, collar, tegula and thorax dark brown; around eye, in haustellum and ventral side of abdomen whitish scales. Antenna $0.9 x$ length of forewing. Neck tuft pale brown. Labial palp dark brown, segment I and upper surface of segment II whitish. Legs dark brown, with numerous paler scales, especially on ventral side of hind leg tibia. Forewing narrow, dark bronzy brown; around fold more or less indistinct dirty brownish yellow streak from base to midwing. Hindwing dark fuscous.

Male genitalia (Fig. 34, Fig. 35). Asymmetrical. Uncus scoop-shaped. Gnathos situated left, stout, curved, terminally strongly sclerotized and rounded with lateral extension. Left valva medioventrally somewhat widened, margin sclerotized; distally tapering, tip pointed, near tip 6-7 strong setae; at base moderately large distinct flap; mediodorsally strongly sclerotized rounded, incised formation; between base and sclerotization flat flap. Right valva basally widened, distally equally thick from middle, curved, at tip cut off and setose; at base distinct flap at middle and weakly sclerotized ridge from flap to tip of valva. Aedeagus moderately long, tapered, subbasally curved. Sternum VIII membranous, subrectangular. Tergum VIII subtriangular, posteriorly slightly asymmetrical.

Female genitalia (Fig. 36). Sterigma asymmetrical, situated at right, strongly sclerotized, curved and tapered, thick horn-shaped formation. Segment VIII furrowed, anterior margin ventrally with rounded, W-shaped indentation, left indentation being deeper than right one. Sternum VII midposteriorly with large, subquadrangular, sclerotized, slightly asymmetrical plate; plate widened with pointed anterior corners and rounded posterior margin. Apophyses posteriores long and slen- 
der. Apophyses anteriores short, straight.

Bionomy. The specimens were swept at midday in sunshine. The biotope was a lowland steppe at an elevation of $250 \mathrm{~m}$ and the species seemed to prefer a dry spot with extremely low vegetation, long grasses being absent. The adults occurred in the beginning of July.

Distribution. Russia (S-Ural). Only known from the type locality.

Etymology. Lat. luxatio = luxation; from the silhouette of the asymmetrical, left weighted male genitalia giving an impression of a man with luxated shoulder.

Remarks. Systematically $S$. luxatiella should be placed in the pulicella species-group, based on the prescence of the setose valvae in the asymmetrical male genitalia, a synapomorphy for the species in this group (Bengtsson 1997). The female genitalia, however, indicate close relationship to S. penicillata Chretien, 1900.

\section{Scythris mikkolai Sinev, 1993}

Ajat river 03.-05.VII.1997, 25.VII.1998; Arkaim 14.19.VI.1996, 07.-10.VII.1997; Berlin 30.VI.-02.VII.1997; Kuvandyk 20.VII.1998; Miass 28.-29.VI.1997, 16.VII.1997; Moskovo 10.-11.VII. 1997, 12.VII.1998; Verbljushka 16.VII.1998.

Distribution. Russia (Primoriye, S Siberia, Samara region). Widely distributed, locally abundant.

Remarks. Males are sometimes flying in swarms in the morning just after sunrise. Before these records $S$. mikkolai was known in Europe only from Samara region (Sachkov 1995). However, the species is not mentioned in the list of European scythridids (Passerin d'Entrèves 1996; Bengtsson 1997).

\section{Scythris obscurella (Scopoli, 1763)}

Bajmak 17.VI.1998; Iremel 24.-27.VI.1996, 25.-28.VI.1999; Miass 26.-29.VI.1997, 29.VI.1999; Moskovo 22.-23.VI.1996; Sakmara river 20.-21.VI.1996. Common.

Distribution. C and S Europe, C Siberia (Baikal region).

Remarks. Occurs mainly at higher elevations and is rare in foothill regions.

\section{Scythris olschwangi K. Nupponen \& T. Nuppo- nen sp. $n$.}

Type material. Holotype: o* (Fig. 37): Russia, southern Urals, $50^{\circ} 45^{\prime} \mathrm{N} 54^{\circ} 28^{\prime} \mathrm{E}, 170 \mathrm{~m}$, Orenburg oblast, Pokrovka village $20 \mathrm{~km} \mathrm{~S}$, Schibendy valley, 04.VI.1998, leg. T. \& K. Nupponen. In coll. T. \& K. Nupponen. Paratypes $\left(7 \sigma^{*} \sigma^{*}\right.$ 4 웅): $60^{\star} 0^{\star}, 3$ 우 우 Same data as holotype; $10^{\star}, 1$ 우 Same data as holotype except date 07.VI.1998. Genitalia slides: K. Nupponen prep. no. 2/14.XI.1998, 2/03.I.1998. Paratypes in the collections of 'T. \& K. Nupponen and Bengt $\AA$. Bengtsson.

Diagnosis. S. olschwangi sp. n. is easy to separate from other known species by the external appearance. Forewing markings are quite similar to those of S. kyzylensis Bengtsson, 1997, but ground colour is different and the moth is more mottled. The genitalia structure also resembles that of kyzylensis, but differs in many details. In the male genitalia good distinguishing marks are ventral extensions of valvae, hooked tip of aedeagus and asymmetrical sternum VIII. In the female genitalia the shape of sterigma is characteristic.

Description. Wingspan 7.5-8.5 mm. Head, antenna, collar, tegula and thorax pale greyish olive brown, posterior margin of thorax and neck tuft slightly paler. Haustellum whitish grey, as well as segment I and segment II of labial palp; segment III of labial palp fuscous. Abdomen in male dorsally fuscous, terminally and ventrally paler; in female anterior half of dorsal side black, posterior half ochreous brown; ventrally beige, occasionally fuscous anteriorly. Forewing pale greyish olive brown with two whitish (in female) or yellowish grey (in male) fasciae at 0.4 and 0.8 from base, the former sometimes reduced to spot in fold; subapically similarly coloured oblique fascia, in male usually subapical spot; in fold indistinct whitish basal spot, distinct black spot at $1 / 4$ and narrow elongate black spot at midwing; on apical side of outer fascia three black spots: broad costal and tornal spots and smaller spot medially, occasionally spots widened forming fascia; ground colour of forewing darkening towards apex from base to inner fascia, as well as from inner fascia to outer fascia. Hindwing in male fuscous, in female fuscous with pale-tipped darker fringe.

Male genitalia (Fig. 38, Fig. 39). Uncus bifurcate, tips incurved and pointed. Base of gnathos circular, terminal part thorn-like, tip slightly 
curved. Valva short, subtriangular, tip rounded, dorsal margin slightly concave at basal $2 / 3$, terminal $1 / 3$ convex; ventral margin with triangular projection. Valvae slightly asymmetrical: right valva narrower and concavity in dorsal margin deeper; projection at ventral margin of right valva thinner and located at 0.4 from base, while that of left valva located at 0.5 from base. Aedeagus long and slender, curved, tip hooked. Sternum VIII asymmetrical, subtriangular with deep anterior indentation, posteriorly with subquadrangular, rounded, oblique extension having strong tooth at base. Tergum VIII subquadrangular, posterior and ventral margins concave, anterior margin slightly asymmetrical with deep V-shaped indentation.

Female genitalia (Fig. 40). Sterigma consists of two separate, parallel, triangular plates. Sternum VII pentangular; medioposterior extension with curved band and straight posterior margin; anterior margin concave with flat, rounded medial extension. Apophyses anteriores $0.5 x$ length of apophyses posteriores.

Bionomy. Specimens were collected in the beginning of June in dry steppe habitat having Artemisia austriaca as a dominant plant. However, the soil is extremely calcareous in the locality and many other food plant candidates also occur in the type locality.

Distribution. Russia (S-Ural). Only recorded from the type locality.

Etymology. We dedicate this species to Dr. Vladimir Olschwang (Ekaterinburg, Russia), who has organized our Ural expeditions.

Remarks. S. olschwangi is a close relative to $S$. kyzylensis Bengtsson, a species recently described from Tuva Rep., southern Siberia. To date these two species are the only ones known belonging to this species-group. In the original description of kyzylensis (Bengtsson 1997a: Fig.14b) the VIII sternal and tergal plates are mixed up.

\section{Scythris perlucidella K. Nupponen \& T. Nup- ponen sp. $n$.}

Type material. Holotype: o (Fig. 41): Russia, southern Urals, $51^{\circ} 23^{\prime} \mathrm{N} 56^{\circ} 49^{\prime} \mathrm{E}, 200 \mathrm{~m}$, Orenburg oblast, Donskoje village $6 \mathrm{~km} \mathrm{W,} \mathrm{Mount} \mathrm{Verbljushka,} \mathrm{30.V.1998,} \mathrm{leg.} \mathrm{T.} \mathrm{\&} \mathrm{K.}$ Nupponen. In coll. T. \& K. Nupponen. Paratypes (143 $\sigma^{\circ} \sigma$, 92 우): Same data as holotype, except for dates: $18 \sigma^{\star} \sigma^{\star}, 6$ 우 우

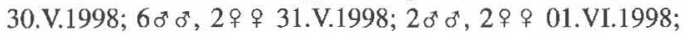

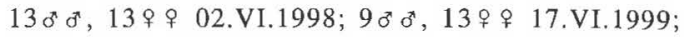
$10 \sigma^{\pi}, 9 q+18$.VI.1999; $7 \sigma^{*}, 5 \%+19$. VI.1999. Same locality as holotype: $47 \sigma^{\pi}, 21$ 우 우 30.V.-02.VI.1998; $7 \sigma^{\star} \sigma^{*}, 7$ 우 10.-12.VI.1998, leg. J. Junnilainen. Russia, southern Urals, $50^{\circ} 40^{\prime} \mathrm{N} 54^{\circ} 26^{\prime} \mathrm{E}, 220 \mathrm{~m}$, Orenburg oblast, Pokrovka village $20 \mathrm{~km} \mathrm{~S}$, Schibendy valley, $2 \sigma^{\star} \sigma^{\star}$, 2 우 우 04.VI.1998, 7 ठే 1 우 07.VI.1998, 1 ㅇ 21.VI.1999,

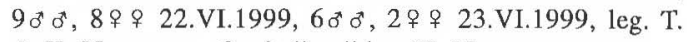
\& K. Nupponen. Genitalia slides: K. Nupponen prep. no. 1/15.XI.1998, 4/03.I.1999; 2 further genitalia preparations preserved in glycerol. Paratypes in the collections of T, \& K. Nupponen, J. Junnilainen, Bengt $\AA$. Bengtsson and Zoological Museum, University of Helsinki.

Diagnosis. Rather easy to separate from other scythridids of equal size by the transparent hindwings. In the male genitalia the shape of valva with strongly curved basal half is very characteristic.

Description. Wingspan 11.5-15 mm. Head, antenna, haustellum, collar, tegula, neck tuft and thorax bronzy greenish, labial palp similarly coloured except segment I and upper surface paler, as well as legs, but hindleg tibia paler. Abdomen dorsally blackish brown with metallic lustre, ventrally pale yellowish brown, basally darker. Forewing bronzy greenish, unicolorous without markings; in some specimens broad, indistinct yellowish green streak in fold from base to cell end and/ or scattered scales of same colour in apical area. Hindwing transparent; scales present only at apical margin and very sparsely elsewhere; fringe brown, basally paler.

Male genitalia (Fig. 42, Fig. 43). Uncus spatular, setose, margins bent and sclerotized, terminally with two flat processes and shallow indentation. Gnathos base subtriangular, furrowed plate; distal part thorn-like, basally wide, apical part thin and bent. Aedeagus long, basally hooked, then slightly bent, tip curved. Valva basally narrow, curved $90^{\circ}$ inwards; distally setose, paddleshaped, dorsal margin straight and near apex curved inwards, ventral margin basally convex and then straight, tip rounded. Sternum VIII subtriangular, terminally rounded with V-shaped median indentation; lateral margin slightly sinuate; anterior margin with broad medial incurvation; anterior corners extended outwards, foot-shaped. Tergum VIII subtrapezoidal, laterally slightly concave, terminally rounded; anterior margin deeply incised.

Female genitalia (Fig. 44). Sterigma weakly sclerotized, membranous, folded. Sternum VII 
subrectangular with posteromedian incision. Apophyses anteriores $2 / 3 x$ length of apophyses posteriores.

Bionomy. The specimens were collected in the end of May and the first half of June. The habitat in both localities was a calcareous steppe slope. Adults were flying in the afternoon sunshine.

Distribution. Russia (S-Ural). The species is only known from Orenburg oblast in the southern Ural region, in two different localities.

Etymology. Lat. perlucidus = transparent. From the transparent hindwings of the moth.

Remark. The taxon belongs to the pascuella species-group.

\section{Scythris productella (Zeller, 1839)}

Chalk Hills 07.VI.1998; Kuvandyk 13.-16.VI. 1998; Novoiletzk 09.VI.1998; Verbljushka 01.-02.VI.1998, 10.12.VI.1998, 17.-19.VI.1999.

Distribution. Europe east to Sarepta (Russia). Locally common.

Remarks. The best habitats for this species were half-shadowed bushy areas close to wet meadows. These records are the easternmost ones known.

\section{Scythris pudorinella (Möschler, 1866)}

Chalk Hills 04.-07.VI.1998; Kidriasovo 28.-29.V.1998, Kuvandyk 16.VI.1998; Kuvandyk 2 16.VI.1998. A total of 18 exx.

Distribution. Greece, Romania, Russia (Sarepta), Turkey, S Siberia (Altai).

Remarks. A rare species. The majority of the specimens $\left(9 \sigma^{\Im} \sigma^{\circ}, 2\right.$ q) were caught during a very favourable moment before a thunderstorm. The habitat was a rocky slope with sparse vegetation.

\section{Scythris remexella K. Nupponen \& Kaitila sp. n.}

Type material. Holotype: $\sigma^{\star}$ (Fig. 45): Russia, southern Urals, $51^{\circ} 30^{\prime} \mathrm{N} 57^{\circ} 30^{\prime} \mathrm{E}, 350 \mathrm{~m}$, Orenburg oblast, Kuvandyk village 12 km SE, 15.VI.1998, leg. T. \& K. Nupponen. In coll. T. \& K. Nupponen. Paratypes (45 o $\sigma^{*}, 19$ ): Russia, southern Urals, $52^{\circ} 40^{\prime} \mathrm{N} 59^{\circ} 30^{\prime} \mathrm{E}, 370 \mathrm{~m}$, Cheliabinsk oblast, Arkaim Reserve near Amurskii village, $8 \sigma^{*} \sigma^{*}, 1$ 0 08.VII.1997, $14 \sigma^{*} \sigma^{*}$ 09.VII.1997 leg. K. Nupponen \& J. Junnilainen; same locality: $6 \sigma^{\star} \sigma^{*}$ 08.VII.1997, $7 \sigma^{*} \sigma^{*}$ 09.VII.1997 leg. J.-P. Kaitila, $1 \sigma^{\circ}$ Russia, southern Urals, $53^{\circ} 00^{\prime} \mathrm{N} 62^{\circ} 05^{\prime} \mathrm{E}, 200 \mathrm{~m}$, Cheliabinsk oblast, Ajat river near Nikolacvka village, 03.VII.1997, leg. K. Nupponen; $10^{n}$ same locality but 04.VII.1997, leg. J.P. Kaitila. $1 \sigma^{7}$ Same data as holotype. Russia, southern Urals, $50^{\circ} 45^{\prime} \mathrm{N} 54^{\circ} 28^{\prime} \mathrm{E}, 170 \mathrm{~m}$, Orenburg oblast, Pokrovka village $20 \mathrm{~km} \mathrm{~S}$, Schibendy valley, $60^{*} \sigma^{*} 22$.VI.1999, $10^{*}$ 23.VI.1999, leg. T. \& K. Nupponen. Genitalia slides: K. Nupponen prep. no. 2/25.IV.1998, 10/25.IV.1998, 2/02.XII.1998 (7); 2 further genitalia preparations preserved in glycerol. In coll. T. \& K. Nupponen, J.-P. Kaitila, J. Junnilainen, Bengt $\AA$. Bengtsson and Zoological Museum, University of Helsinki.

Diagnosis. Habitually resembling S. acipenserella sp. $\mathrm{n}$. (see above) but differing from that by less contrastic greyish brown forewing with more distinct dark spot at cell end. The male genitalia with four conspicuous oar-shaped formations are rather complex, impossible to be confused with those of any other known species.

Description. Wingspan 6.5-8.5 mm. Head, antenna, collar, tegula and thorax greyish brown. Labial palp, haustellum and neck tuft dirty beige, eye surrounded with same colour; labial palp short, less than $1.5 \mathrm{x}$ diameter of eye. Legs brown, mixed with beige scales, hind legs paler. Abdomen dorsally dark fuscous; ventral side basally dark fuscous, terminal half greyish beige, paler in female. Forewing greyish brown, darker at base of costa and around apex; in fold pale beige streak, slightly broadening towards tornus, narrowed by dark brown spot at midwing; another, larger dark brown spot at cell end; tornal spot moderately distinct, pale beige; near apex more or less indistinct paler area. Hindwing dark fuscous.

Male genitalia (Fig. 46, Fig. 47). Uncus subquadrangular with deep, V-shaped medioposterior incision; tips triangular, concave and terminally pointed. Gnathos thick, terminally sclerotized with three pointed extensions; ventrally two slightly curved broad projections; from base backward two long, narrow formations with elliptical terminal process. Tegumen laterally extended, with two huge oar-shaped processes. Aedeagus bottleshaped, slightly curved, medially broadest. Valvae short, concave, cup-shaped, medially fused. Sternum VIII subrectangular, slightly arched, anteriorly incurved, posteriorly with flat protrusion. Tergum VIII subrectangular, more or less membranous.

Female genitalia (Fig. 48). Sterigma subquadrangular, posteriorly with rounded medial protrusion, anteriorly with V-shaped dorsal incision; posterior half more strongly sclerotized; scleroti- 
zation extended anteriorly to margin of segment VIII. Sternum VII subtrapezoid, posteriorly with median incurvation. Apophyses posteriores long and slender. Apophyses anteriores $0.4 \mathrm{x}$ length of apophyses posteriores.

Bionomy. S. remexella sp. n. occurs in dry, hot lowland steppes at an elevation of $200-400 \mathrm{~m}$ with Artemisia austriaca as a dominant plant. The moth was active in sunny afternoons. It did not fly willingly but jumped among the vegetation. Therefore, sweeping was the only effective method to collect the species. Specimens have been observed from mid-June to the first third of July. After three years of experience, we concluded that $S$. remexella seems to have a relatively short flight period.

Distribution. Russia (S-Ural). The species is known only from Cheliabinsk and Orenburg oblasts in the southern Ural region, in four different localities (see also Remarks).

Etymology. Lat. remex $=$ oarsman; from the four large oar-shaped formations in the male genitalia.

Remarks. S. remexella is a local species, but very probably distributed not only in the southern Urals but also eastward along the Russian and Kazakh steppe zones. The combination of characters in the male and female genitalia does not coincide with any known species-group. Because of complexity, the male genitalia are difficult to set in a visual position during preparation process. We recommend to preserve the preparations in glycerol to allow three-dimensional examination.

\section{Scythris setiella (Zeller, 1871)}

Arkaim 08.-09.VII.1997; Burannoe 20.-21.VI. 1999; Chalk Hills 04.-07.VI.1998, 18.VII.1998, 21.-23.VI.1999; Kidriasovo 16.VI.1999; Kuvandyk 14.VI.1998; Kuvandyk 2 16.VI.1998; Verbljushka 01.-02.VI.1998, 10-.12.VI.1998, 17.-19.VI.1999. About 120 exx. collected.

Distribution. Russia (Sarepta region).

Remarks. Occurs in steppe habitats, often in lower part of hot slopes. All specimens were caught by sweeping on Linosyris villosa (L.), evidently the food plant of setiella.

\section{Scythris sinensis (Felder \& Rogenhofer, 1875)}

Kuvandyk 14,-16.VI.1998. 1 ex.
Distribution. Northern half of the Palaearctic region, excluding arctic areas.

Remark. The specimen came to artificial light.

\section{Scythris subaerariella (Stainton, 1867)}

Ajat river 03.-05.VII.1997; Arkaim 07.-10.VII. 1997, 22.VII.1998; Berlin 30.VI.-02.VII.1997; Kuvandyk 20.VII.1998; Moskovo 10.-1I.VII. 1997, 11.-12.VII.1998.

Distribution. Bulgaria, Greece, Turkey. Not abundant.

Remarks. These records are the easternmost ones known. New to Russia.

\section{Scythris sublaminella K. Nupponen \& T. Nup- ponen sp. $\mathbf{n}$.}

Type material. Holotype: o (Fig. 49): Russia, southern Urals, $51^{\circ} 13^{\prime} \mathrm{N} 57^{\circ} 37^{\prime} \mathrm{E}, 350 \mathrm{~m}$, Orenburg oblast, Mednogorsk 20 $\mathrm{km}$ S, near Kidriasovo village, 29.V.1998, leg. T. \& K. Nupponen. In coll. T. \& K. Nupponen. Paratypes ( $\left.23 \sigma^{\circ} \sigma, 5 q \%\right)$ : $1 \sigma^{7}$ Same data as holotype. $10 \sigma^{\circ} \sigma^{7}, 1$ i Russia, southern Urals, $50^{\circ} 59^{\prime} \mathrm{N} 57^{\circ} 17-22^{\prime} \mathrm{E}, 100 \mathrm{~m}$, Orenburg oblast, Novoiletzk 8 km E, 09.VI.1998, leg. T. \& K. Nupponen. 2 o o $^{*}$ Same locality as previous paratypes but 08 .VI.1999, leg. J. Junnilainen. Russia, southern Urals, $51^{\circ} 23^{\prime} \mathrm{N} 56^{\circ} 49^{\prime} \mathrm{E}, 140 \mathrm{~m}$, Orenburg oblast, Donskoje village $6 \mathrm{~km}$ W, mount Verbljushka, $1 \sigma^{*}, 3$ 우 우 11.VI.1998, 7 đ゙ $^{*} 1$ 우 17.VI.1999, $10^{\star}$ 18.VI.1999, leg. T. \& K. Nupponen. $10^{*}$ Russia, southern Urals, $50^{\circ} 40^{\prime} \mathrm{N}$ $54^{\circ} 26^{\prime} \mathrm{E}, 190 \mathrm{~m}$, Orenburg oblast, Pokrovka village $20 \mathrm{~km}$ S, Schibendy valley, 05.VI.1998, leg. T. \& K. Nupponen. Genitalia slides: K. Nupponen prep. no. 5/14.XI.1998, 6/ 14.XI.1998, 3/03.I.1999; 2 further genitalia preparations preserved in glycerol. Paratypes in the collections of T. \& K. Nupponen, J. Junnilainen and Bengt $\AA$. Bengtsson.

Diagnosis. Externally $S$. sublaminella sp. n. may be confused with many other small, dark scythridids. The genitalia structure resembles that of S. laminella (Denis \& Schiffermüller, 1775). The main characters distinguishing the new taxon are in the male genitalia: more curved valva with a characteristic semicircular lateral extension at base, more bent aedeagus and in sternum VIII two digitate processes being absent in laminella. In the female genitalia the conical sterigma is more slender and sclerotized.

Description. Wingspan 8-9.5 mm. Head, antenna, tegula, thorax and legs dark brown. Collar, neck tuft and haustellum slightly paler brown. Labial palp dark brown, more or less mixed with paler brown scales, especially at base. Abdomen dorsally fuscous, ventrally pale brown, basal 1/4 darker. Forewing dark brown with weak purplish 
lustre, mixed with paler brown scales; pale scales are more numerous in apical half and form more or less indistinct streak in fold from base to midwing. Hindwing fuscous, moderately narrow.

Male genitalia (Fig. 50, Fig. 51). Tegumen hood-shaped, posteriorly extended and wrinkled. Uncus and gnathos reduced, latter being replaced by socii. Aedeagus curved, tapered. Valva narrow, longish, curved; ventrally large, semicircular process near base; apex pointed; shallow fold at middle of valva. Basal part of sternum VIII subrectangular, anterior margin concave; posterior part semicircular, slightly asymmetrical, with two posterolateral digitate processes [another one broken in Fig. 51]. Tergum VIII slightly asymmetrical, subtriangular, anterior margin incised, medioposterior process thick, tapered and pointed.

Female genitalia (Fig. 52). Sterigma stumplike cone with U-shaped posterior incision and wide, triangular, weakly sclerotized anterior extension. Anterior margin of sternum VIII incised. Sternum VII subquadrangular; posterior margin convex, medially straight but uneven. Apophyses anteriores $0.5 \mathrm{x}$ length of apophyses posteriores.

Bionomy. The specimens were observed in the end of May and the first half of June in lowland Artemisia steppes, preferably close to wet meadows.

Distribution. Russia (S-Ural). The species is only known from Orenburg oblast in the southern Ural region, from four different localities.

Etymology. Lat. $s u b=$ near. The name $s u b$ laminella refers to the close affinity in genital morphology to $S$. laminella (Denis \& Schiffermüller, 1775).

Remark. The new taxon belongs to the laminella species-group.

\section{Scythris tributella (Zeller, 1847)}

Chalk Hills 07.VI.1998, 22.-23.VI.1999; Verbljushka 10.12.VI.1998. A total of 5 exx.

Distribution. C and S Europe, Libya.

\section{Scythris sp.}

Material. 1 우 (Fig. 53): Russia, southern Urals, $50^{\circ} 40^{\prime} \mathrm{N}$ $54^{\circ} 26^{\prime} \mathrm{E}, 230 \mathrm{~m}$, Orenburg district, Pokrovka village $20 \mathrm{~km}$ S, Schibendy valley, 07.VI.1998, leg. T. \& K. Nupponen.
Genitalia slide: K. Nupponen prep. no. 5/03.I.1998. In coll. T. \& K. Nupponen.

External appearance. Wingspan $11.5 \mathrm{~mm}$. Head, antenna, collar, tegula and thorax olive brown. Neck tuft, haustellum and labial palp creamy brown, legs pale brown. Abdomen dorsally blackish, basally lead-grey spot and narrow band, two terminal segments yellowish creamcoloured; ventrally pale greyish yellow, basally and laterally with lead-grey scales. Forewing purplish bronzy brown, olive-tinged; in fold several blackish brown scales forming indistinct streak; small cream-coloured spot basally at fold, similarly coloured big spot in fold at 0.4 and another one at cell end reaching tornus; subapically moderately distinct small black spot. Hindwing moderately broad, brown, fringe basally paler.

Female genitalia (Fig. 54). Sterigma slightly asymmetrical, dome-shaped plate; posterior part thick, laterally shallowly concave, terminal margin straight, anterior margin uneven; shanks thick with incised apex, right one being longer. Ductus bursae sclerotized, posterior part broader. Sternum VII subrectangular with shallow posteromedian incurvation. Apophyses anteriores $0.6 \mathrm{x}$ length of apophyses posteriores.

Remarks. The combination of characters in the female genitalia and external appearance does not coincide with any known species. 'The forewings of the specimen are slightly worn and therefore the markings are not sharply visible. Although this taxon is most likely unknown, we refrain from describing a new species for the present until more material is available for study.

\section{Parascythris muelleri (Mann, 1871)}

Berlin 02.VII.1997; Miass 13.VI.1996, 26.VI. 1996; Moskovo 19.VI.1998; Verbljushka 11.VI. 1998, 17.VI.1999.

Distribution. C and E Europe. Widely distributed but not common.

\section{Eretmocera medinella (Staudinger, 1859)}

Burannoe 20.VI.1999. 1 \%

Distribution. Mediterranean region, Transcaucasia, Iran, Central Asia.

Remark. New to Russia. 


\section{Discussion}

The scythridid fauna in the southern Ural region is an interesting mixture between European and Asian elements which can be expected as the Ural Mountains may be regarded as a divider between the western and eastern Palaearctic fauna. The European fauna seems to dominate in the southern Urals. Of 37 recorded species 14 are distributed only in Europe (including Turkey), 6 species have a West-Palaearctic distribution range, 1 species is trans-Palaearctic, 1 species is widely distributed in the south and only 2 species are clearly Asiatic.

However, no less than 13 of the recorded species are known only from the southern Urals. In reality, many of them belong to the eastern fauna but a few species might be endemic to the Ural region. Iranian/Anatolian species are absent in the southern Urals as we did not record any scythridids having this kind of southern distribution range.

As a conclusion, the scythridid fauna is very rich in the region studied. The results clearly show that central and eastern Palaearctic scythridids are still poorly known and many species may have much wider distribution range or may show a different distribution pattern than we know to date.

Acknowledgements. We thank the following persons for guide services, assistance, company or other kind of help during our expeditions: Mr. Matti Ahola (Reisjärvi, Finland), Mr. Vladimir Basov (Ijevsk, Russia), Mr. Pavel Gorbunov (Ekaterinburg, Russia), Mr. S. V. Kornev (Orenburg, Russia), Mr. L. V. Korshikov (Orenburg, Russia), Dr. Alexander Lagunov (Miass, Russia), Mr. Alexander Malozemov (Ekater- inburg, Russia), Mr. Yuri Mikhailov (Novouralsk, Russia), Mrs. Elena Nupponen (Espoo, Finland). Our thanks are also due to Mr. Kimmo Silvonen (Espoo, Finland) and Mr. Bo Wikström (Nummela, Finland) for their help in processing most of the photographs. Finally, we are grateful to the Lepidopterological Society of Finland for a partial grant to two expeditions.

\section{References}

Baran, T. 1996: Studies on the Scythrididae (Lepidoptera) of Poland. II. Records of rare species. - Polskie Pismo Entomologiczne 65: 259-265.

Bengtsson, B. §. 1997: Scythrididae. - In: Huemer, P., Karsholt, O. \& Lyneborg, L. (eds.): Microlepidoptera of Europe 2: 1-301.

Bengtsson, B. A. 1997a: Notes on interesting scythridids in the Zoological Museum, Helsinki, Finland (Lepidoptera, Scythrididae). - Entomologica Fennica 8: 89-102.

Bengtsson, B. Å. 1997b: Scythridids found by H. Hacker in Pakistan 1988 and India 1992. - Esperiana 4: 467-481.

Bengtsson, B. Å. \& Liška, J. 1996: Notes on Asian scythridids with description of four new species (Lepidoptera, Scythrididae). - Phegea 24: 33-39.

Bengtsson, B. A. \& Sutter, R. 1996: Scythris felixi sp. n. (Insecta, Lepidoptera: Scythrididae) aus der Mongolei. - Reichenbachia Mus. Tierk. Dresden 31, Nr. 37: 207208.

Eversmann, E. 1844: Fauna Lepidopterologica Volgo Uralensis. - Casani Typis Universitatis. XIV + 633 pp.

Passerin d'Entrèves, P. 1996: Scythrididae. - In: Ole Karsholt \& Josef Razowski (eds.): The Lepidoptera of Europe: 74-78.

Sachkov, S. 1995: New for Europe species of Microlepidoptera (Lepidoptera: Scythrididae, Elachistidae) from Samara region. - Actias 2(1-2), December 1995 (1996): 77-78.

Sinev, S. Y. 1993: New and little-known species of the genus Scythris (Lepidoptera, Scythrididae) from Altai. - Vestnik zoologii 2: 53-57. (In Russian) 


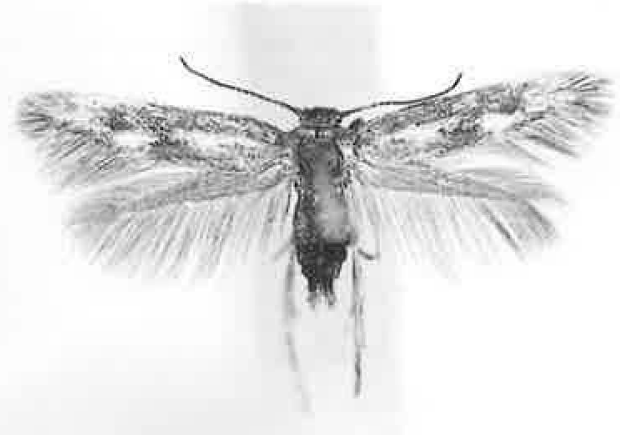

Fig. 4. Imago (holotype) of Scythris acipenserella K. \& T. Nupponen sp. $\mathrm{n}$.

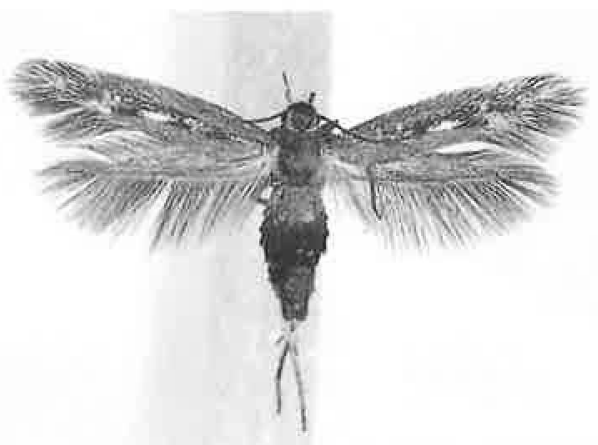

Fig. 12. Imago (holotype) of Scythris albisaxella K. \& T. Nupponen sp. $\mathrm{n}$.

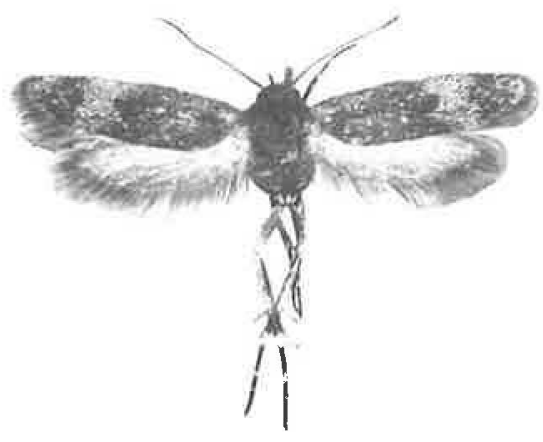

Fig. 18. Imago (holotype) of Scythris brunneofasciella K. Nupponen \& Junnilainen sp. $\mathbf{n}$.

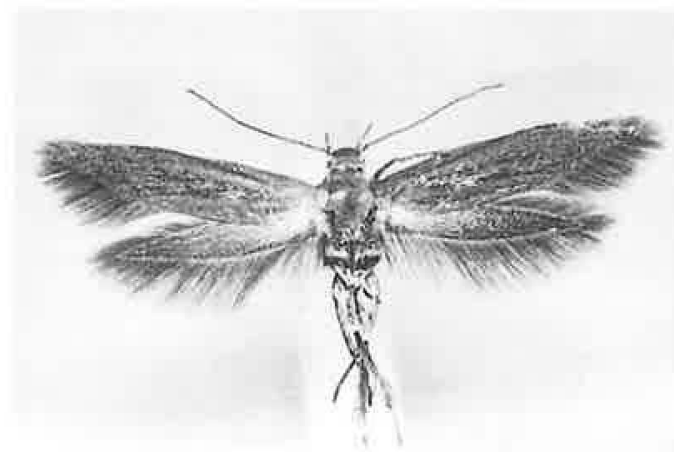

Fig. 8. Imago (holotype) of Scythris aegrella K. Nupponen \& Junnilainen sp. $\mathrm{n}$.

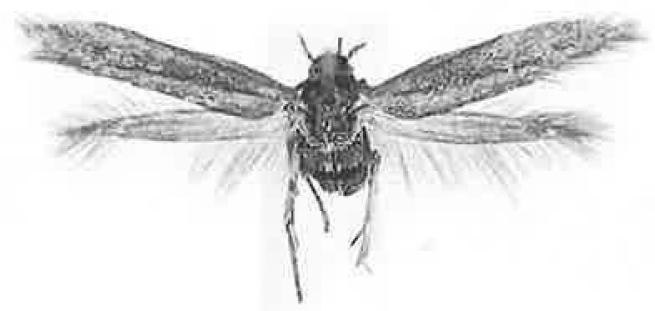

Fig. 16. Imago (holotype) of Scythris arkaimensis Bengtsson sp. $\mathrm{n}$.

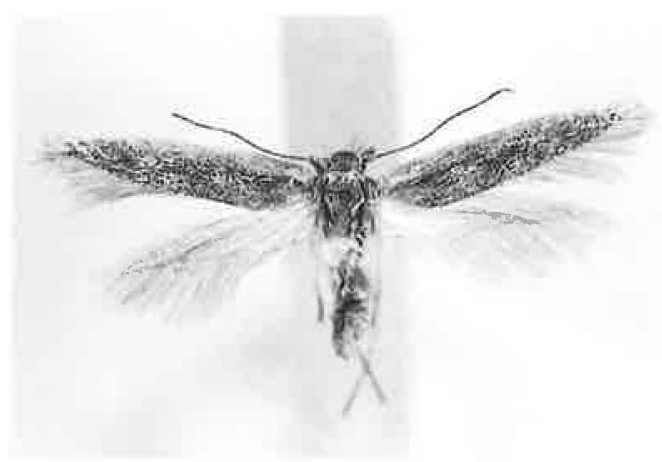

Fig. 20. Imago (holotype) of Scythris cretacella K. \& T. Nupponen sp. $\mathrm{n}$. 


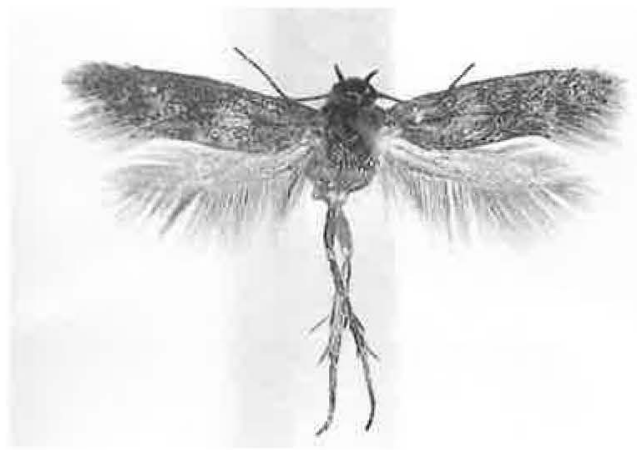

Fig. 22. Imago (holotype) of Scythris elenae K. Nupponen sp. $\mathrm{n}$.

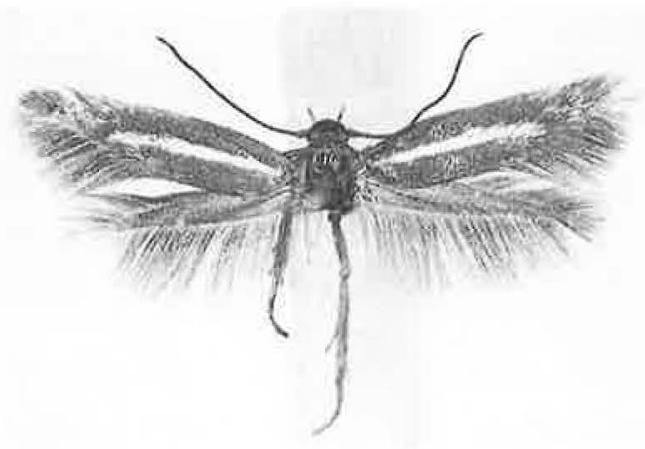

Fig. 29. Imago (holotype) of Scythris karinupponeni Bengtsson sp. $\mathrm{n}$.

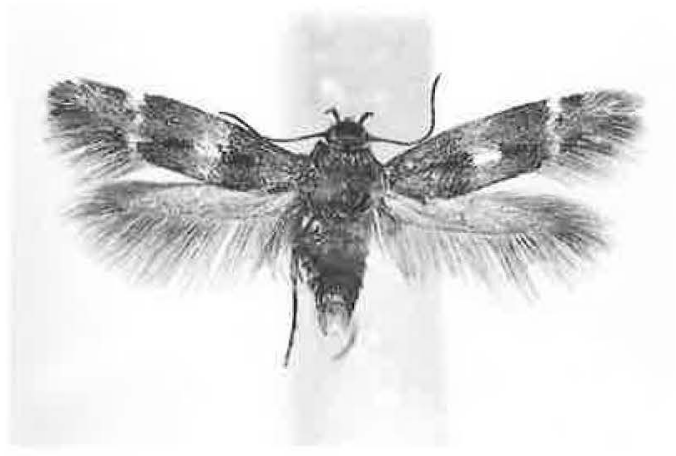

Fig. 37. Imago (holotype) of Scythris olschwangi K. \&. T. Nupponen sp. $\mathrm{n}$.

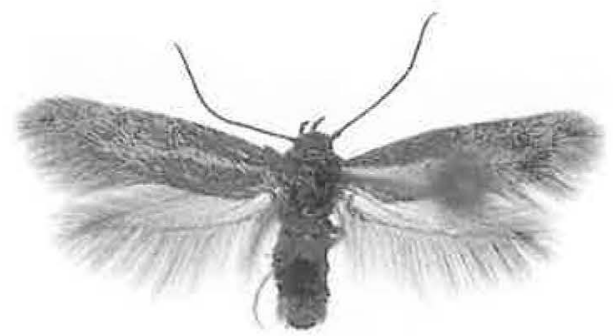

Fig. 25. Imago (holotype) of Scythris eversmanni K. \& T. Nupponen sp. n.

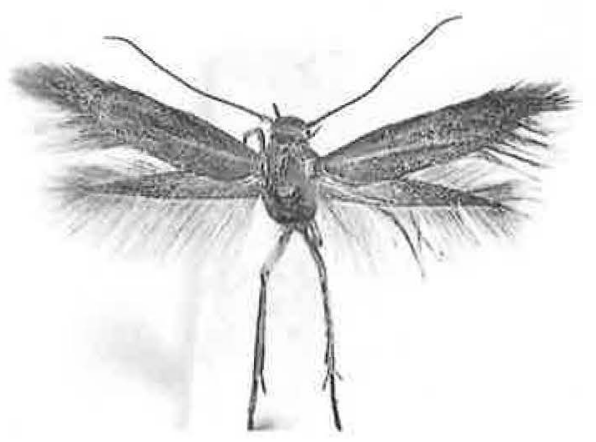

Fig. 33. Imago (holotype) of Scythris luxatiella K. Nupponen \& Kaitila sp. $\mathbf{n}$.

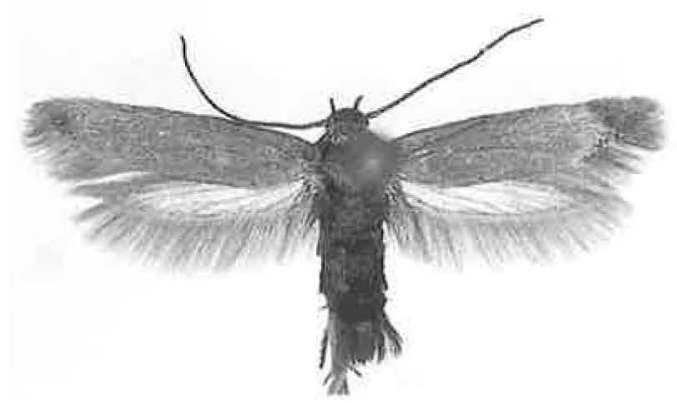

Fig. 41. Imago (holotype) of Scythris perlucidella K. \& T. Nupponen sp. $\mathrm{n}$. 


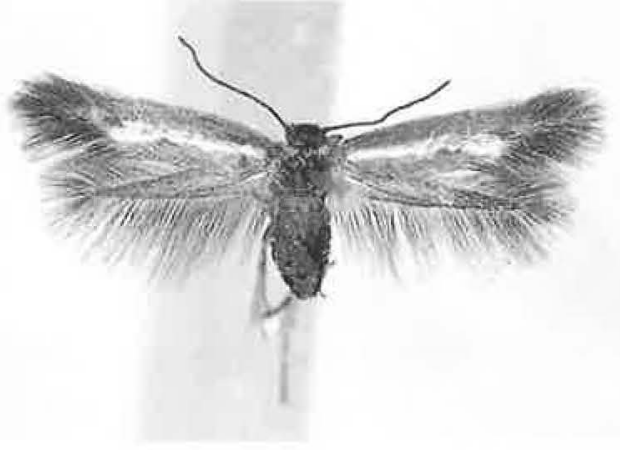

Fig. 45. Imago (holotype) of Scythris remexella K. Nupponen \& Kaitila sp. $n$.

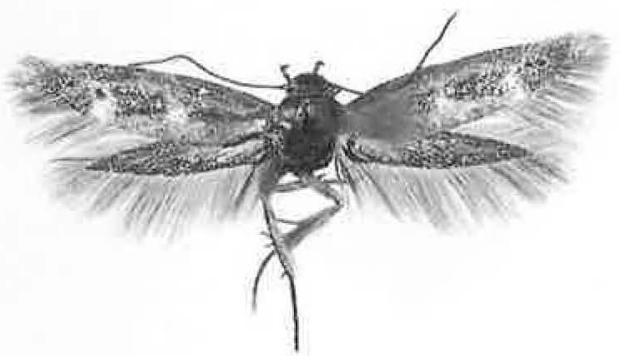

Fig. 53. Imago of Scythris sp. (female).

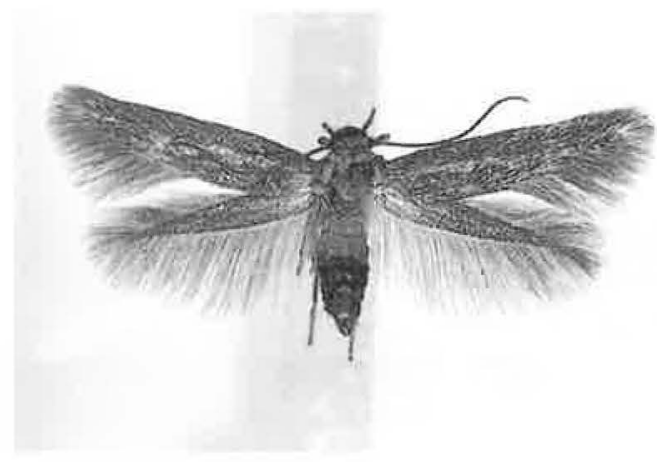

Fig. 49. Imago (holotype) of Scythris sublaminella K. \& T. Nupponen sp. $\mathrm{n}$.

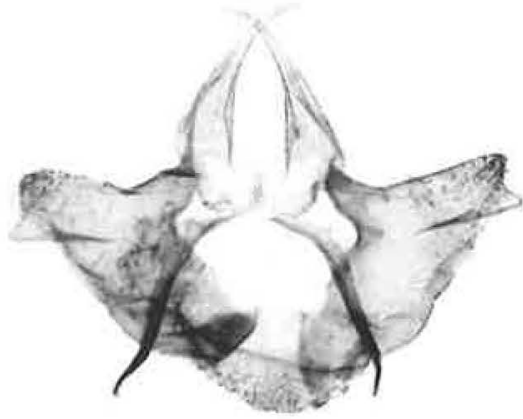

Fig. 6. Tergum VIII (up) and sternum VIII (down) of Scythris acipenserella.

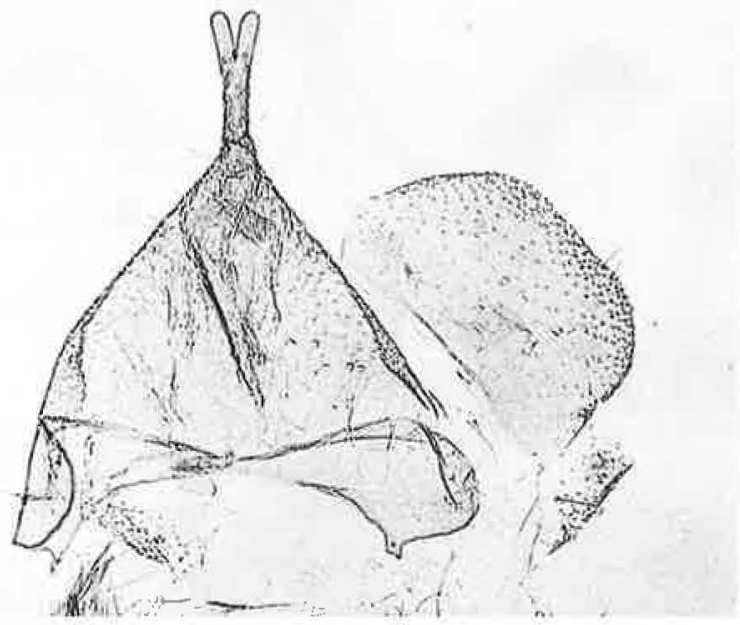

Fig. 10. Sternum VIII (left) and tergum VIII (right) of Scythris aegrella. 

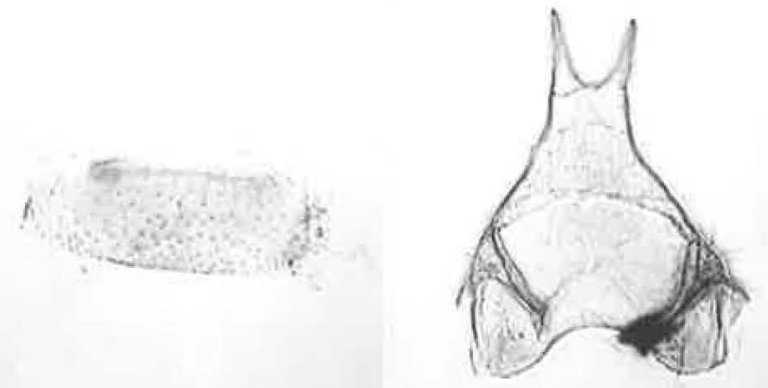

Fig. 14. Sternum VIII (left) and tergum VIII (right) of Scythris albisaxella.
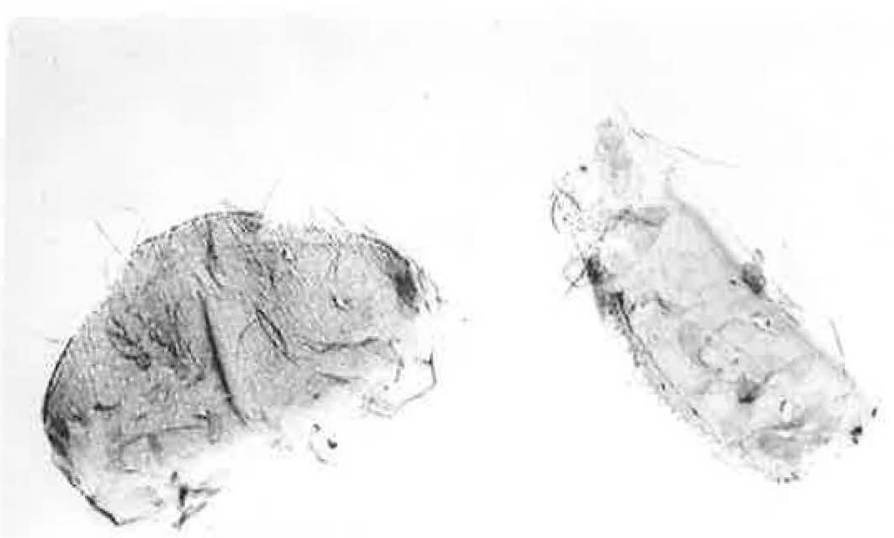

Fig. 24. Sternum VIII (left) and tergum VIII (right) of Scythris elenae.

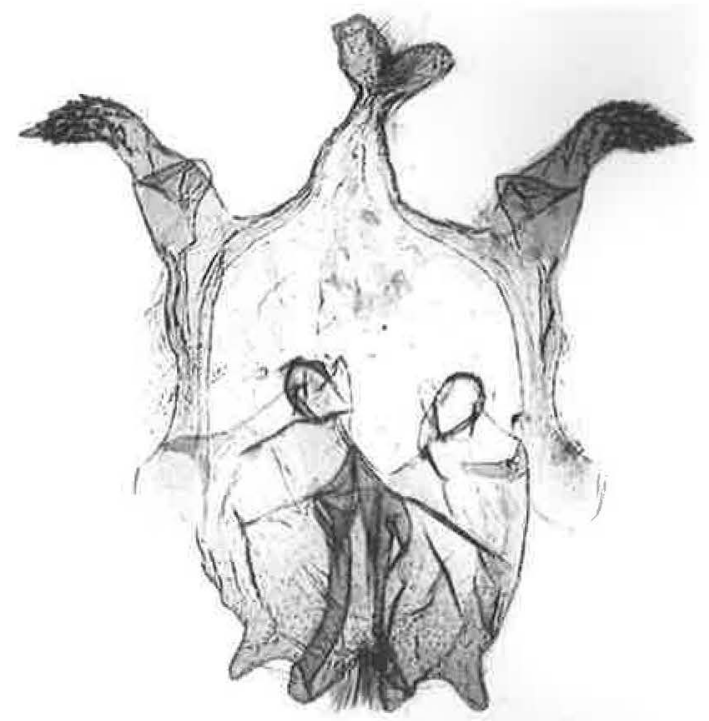

Fig. 27. Sternum VIII (down) and tergum VIII (up) of Scythris eversmanni. 

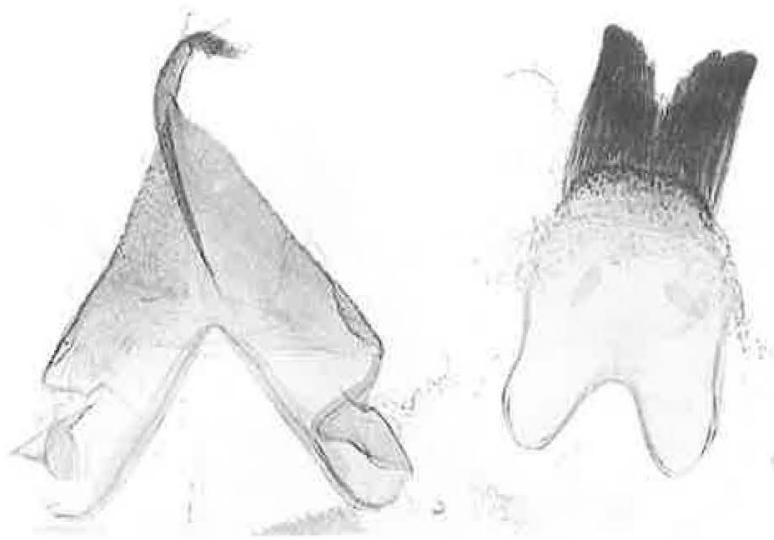

Fig. 31. Sternum VIII (left) and tergum VIII (right) of Scythris karinupponeni.

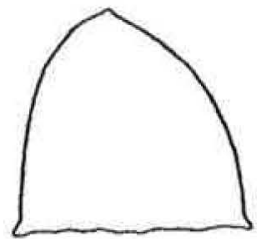

T8

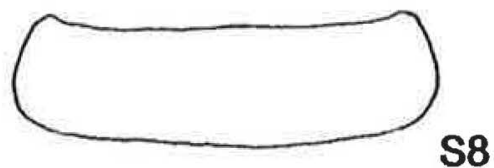

S8

Fig. 35. Tergum VIII (up) and sternum VIII (down) of Scythris luxatiella.

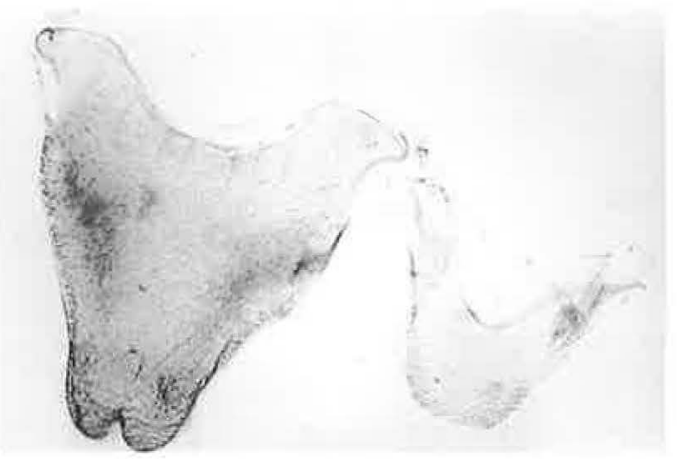

Fig. 43. Sternum VIII (left) and tergum VIII (right) of Scythris perlucidella.

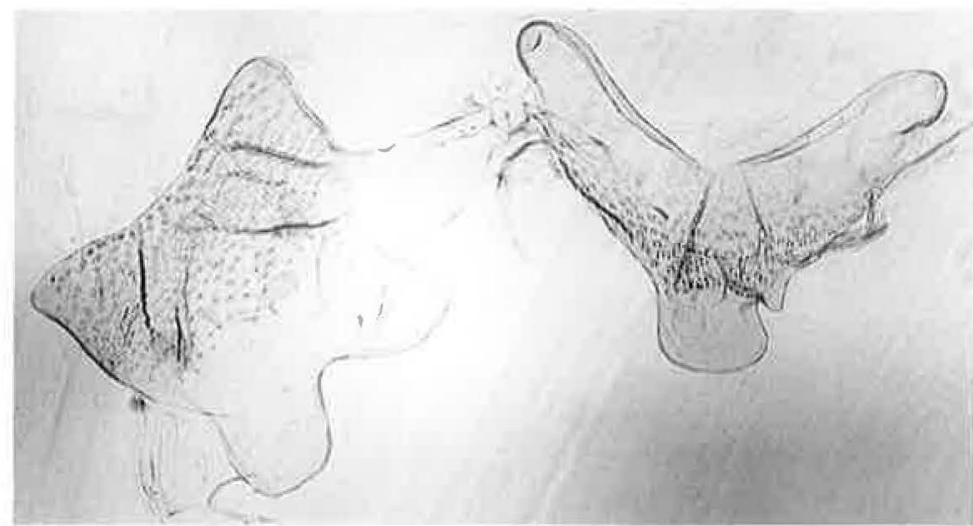

Fig. 39. Tergum VIII (left) and sternum VIII (right) of Scythris olschwangi. 


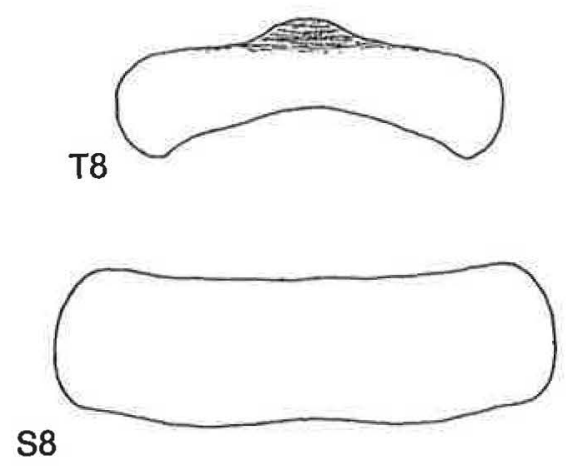

Fig. 47. Tergum VIII (up) and sternum VIII (down) of Scythris remexella.

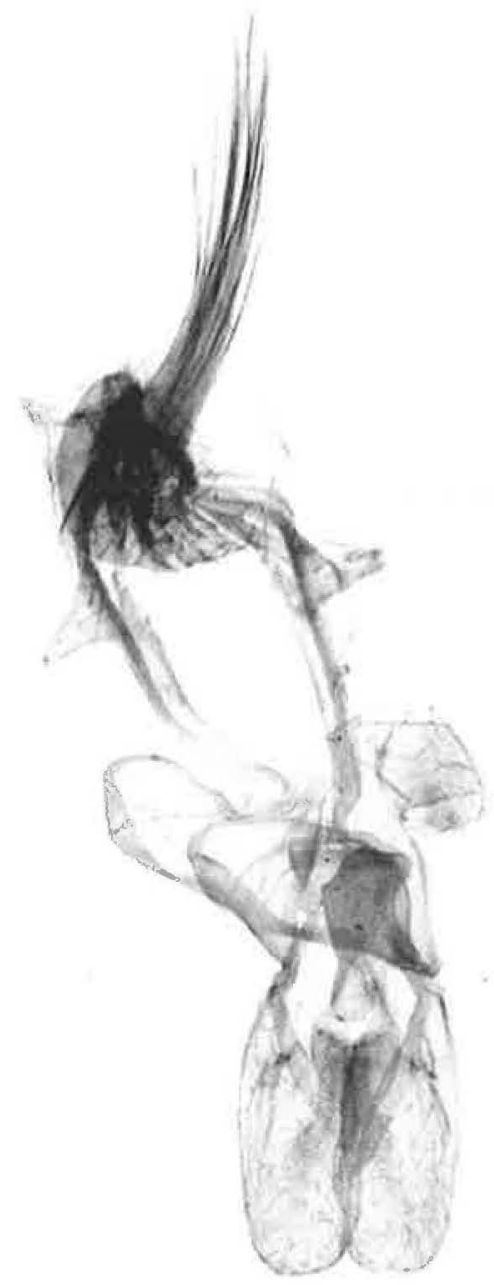

Fig. 5. Male genitalia of Scythris acipenserella (paratype).

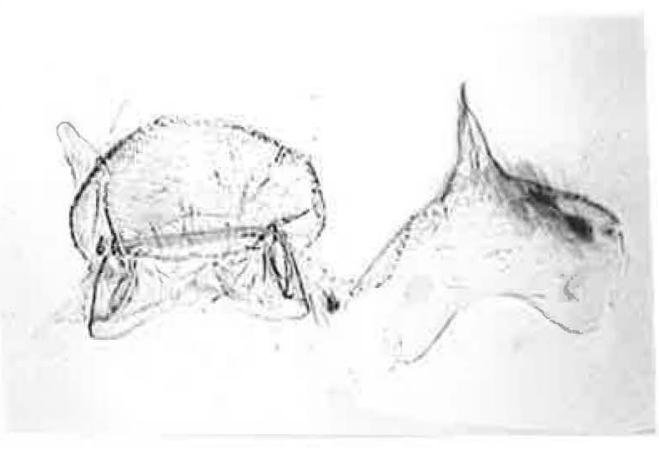

Fig. 51. Sternum VIII (left) and tergum VIII (right) of Scythris sublaminella.

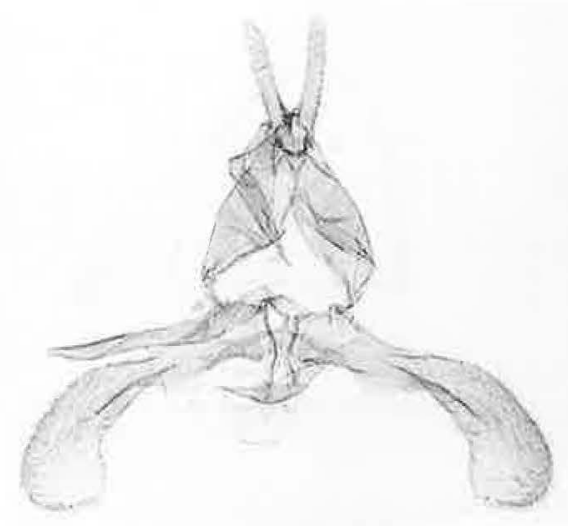

Fig. 9. Male genitalia of Scythris aegrella (holotype).

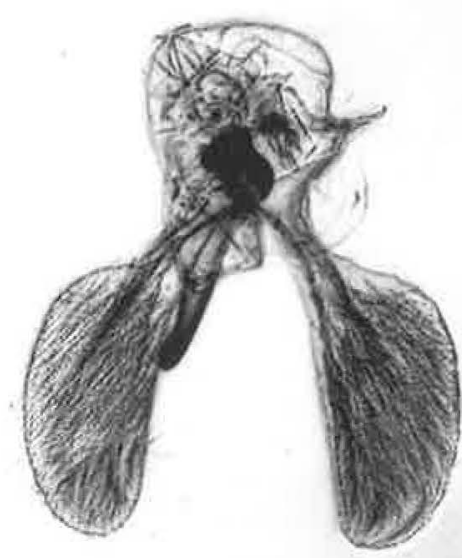

Fig. 13. Male genitalia of Scythris albisaxella (paratype). 


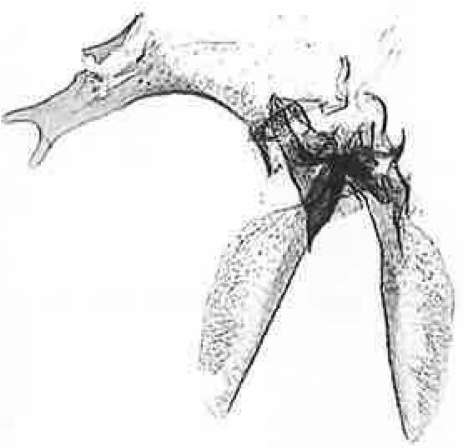

Fig. 17. Male genitalia of Scythris arkaimensis (holotype).

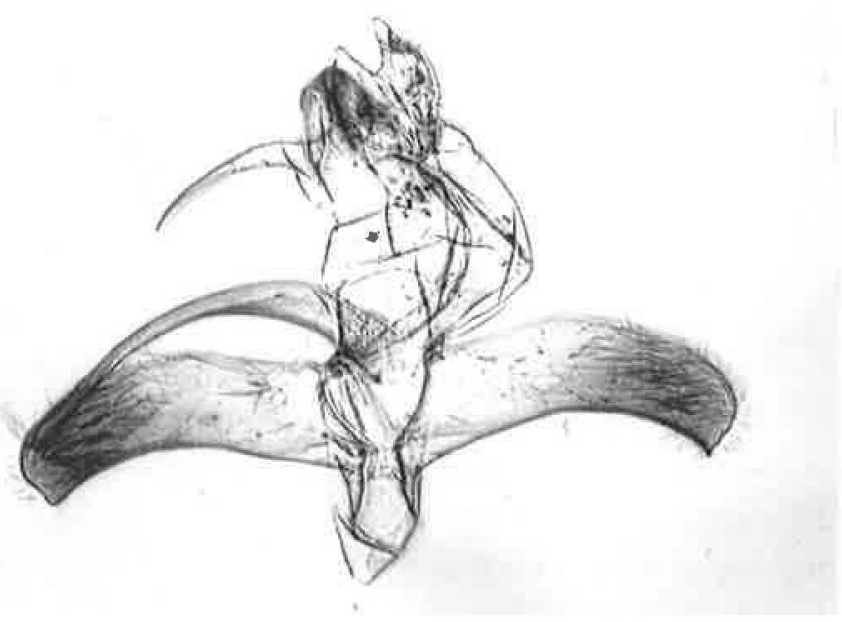

Fig. 23. Male genitalia of Scythris elenae (holotype).

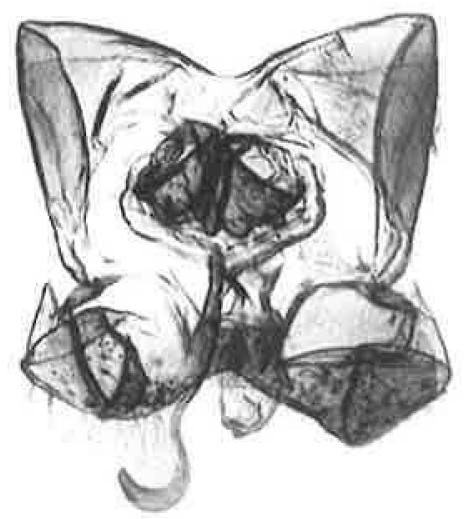

Fig. 26. Male genitalia of Scythris eversmanni (paratype). 


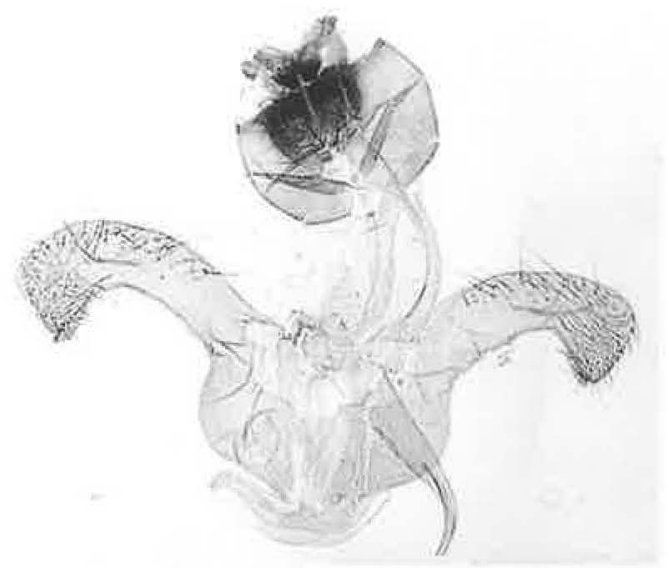

Fig. 30. Male genitalia of Scythris karinupponeni (holotype).

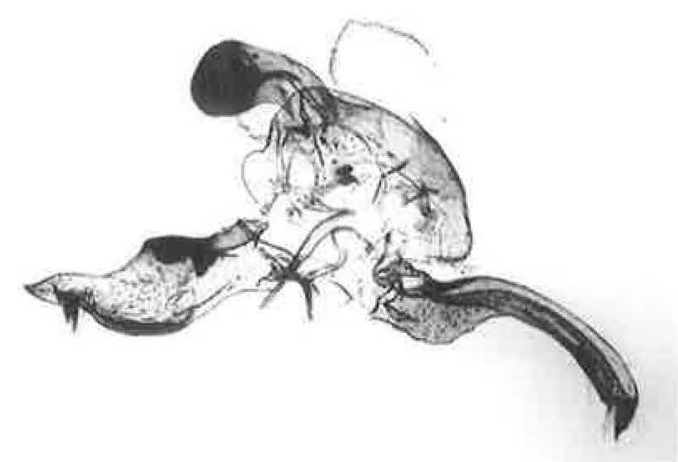

Fig. 34. Male genitalia of Scythris luxatiella (holotype).

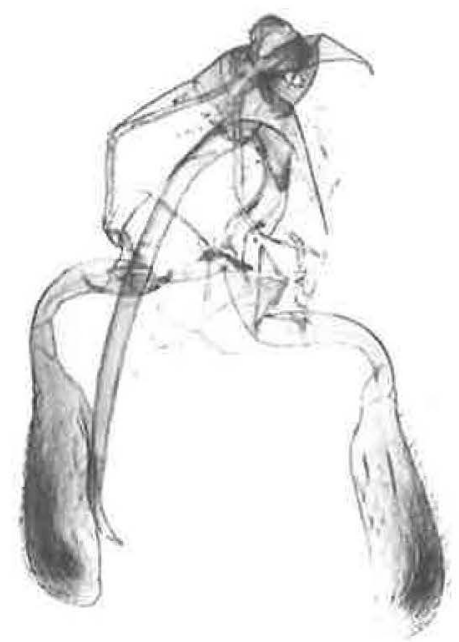

Fig. 42. Male genitalia of Scythris perlucidella (paratype).

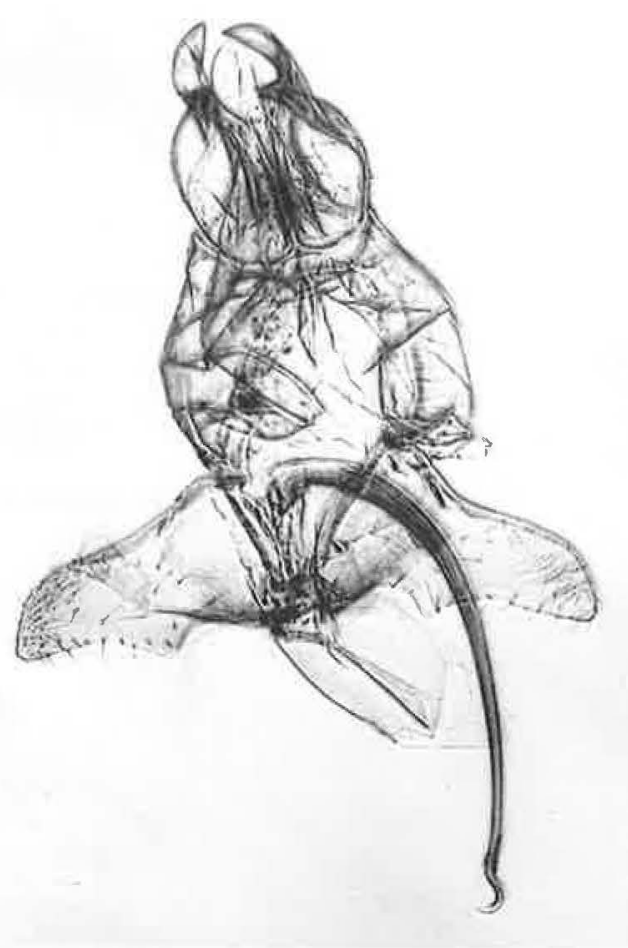

Fig. 38. Male genitalia of Scythris olschwangi (paratype).

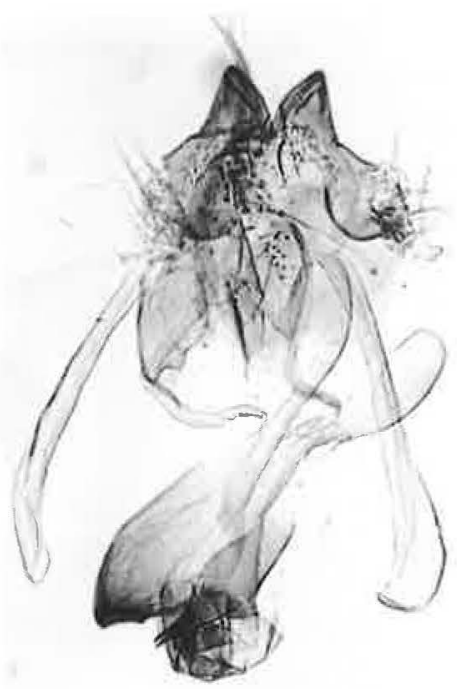

Fig. 46. Male genitalia of Scythris remexella (paratype). 


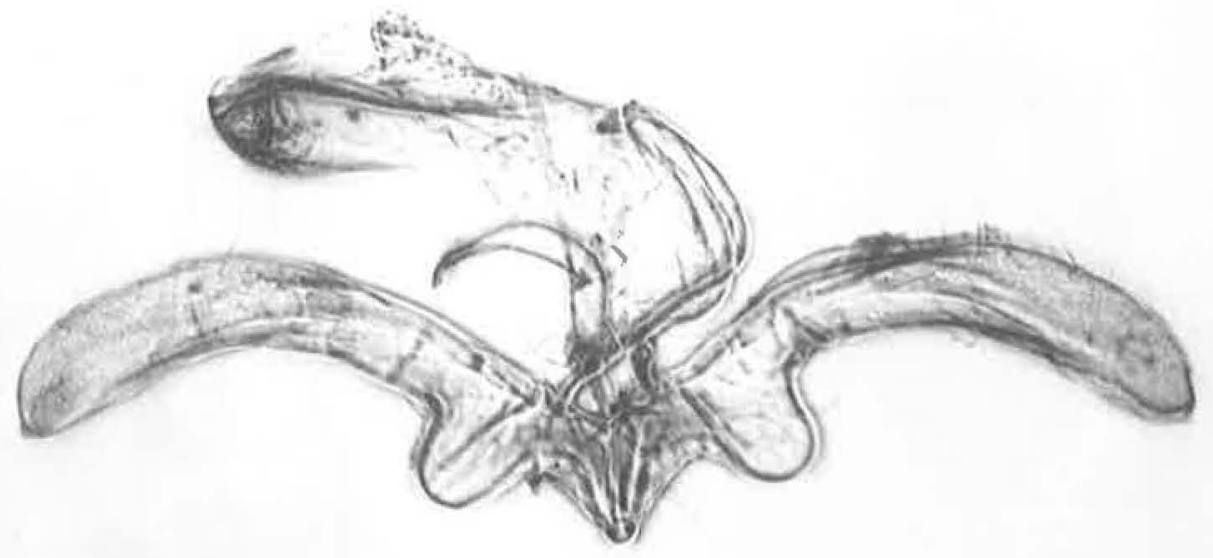

Fig. 50. Male genitalia of Scythris sublaminella (paratype).

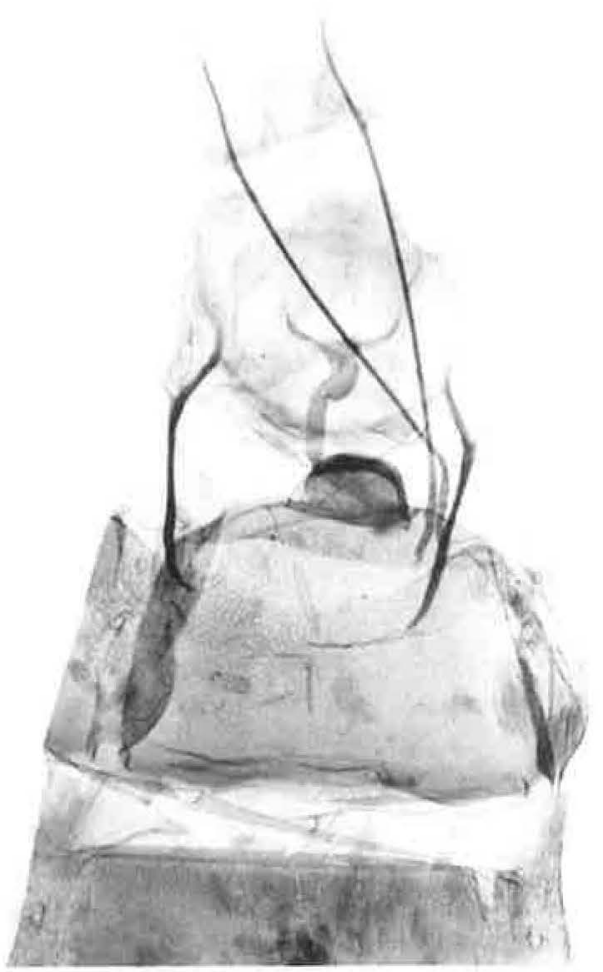

Fig. 11. Female genitalia of Scythris aegrella (paratype).

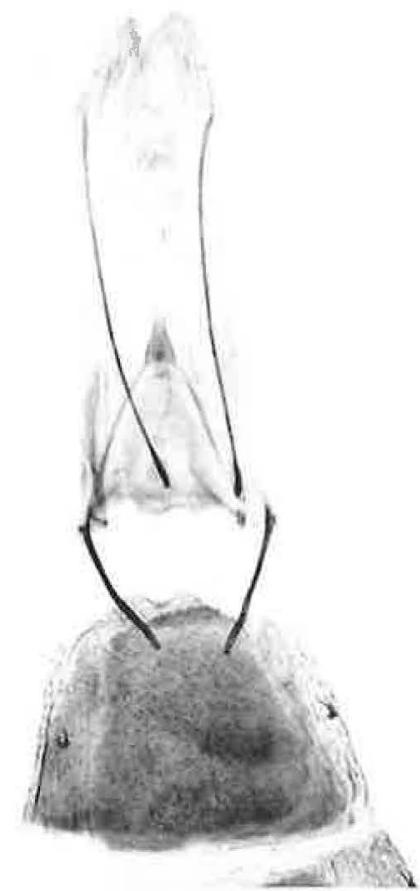

Fig. 15. Female genitalia of Scythris albisaxella. 


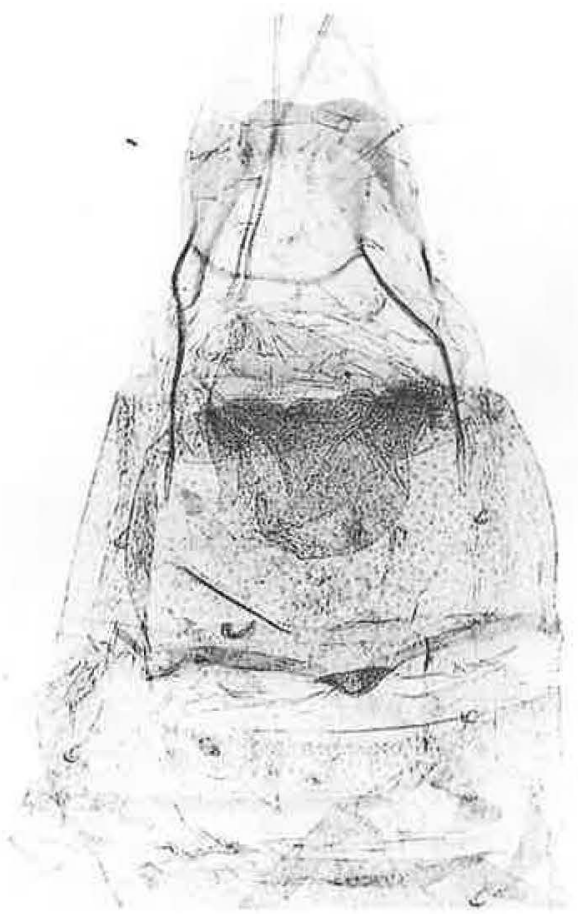

Fig. 19. Female genitalia of Scythris brunneofasciella (holotype).

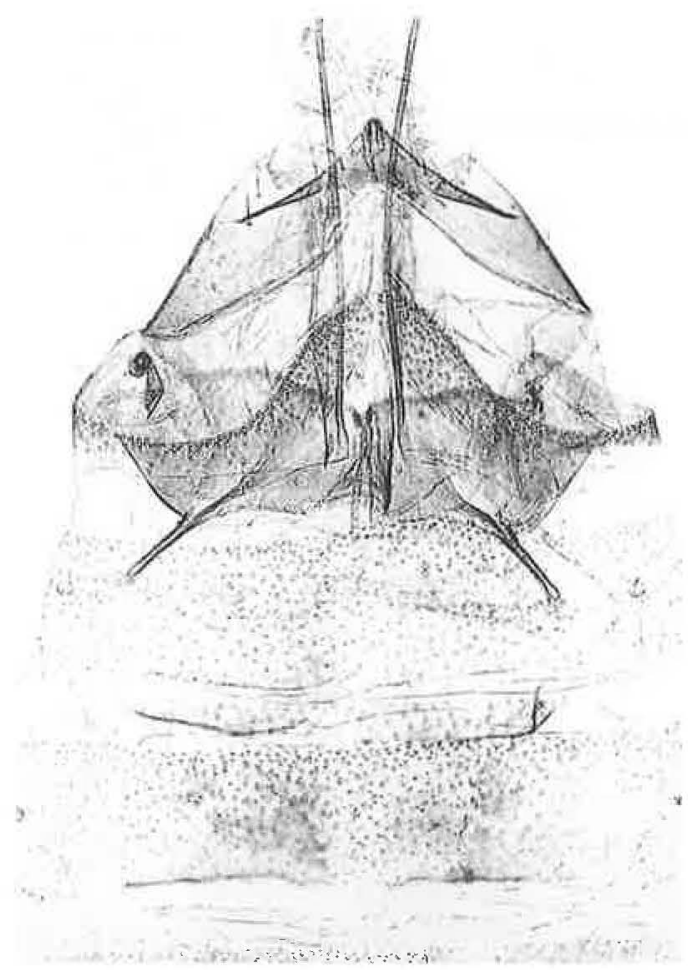

Fig. 28. Female genitalia of Scythris eversmanni (paratype).

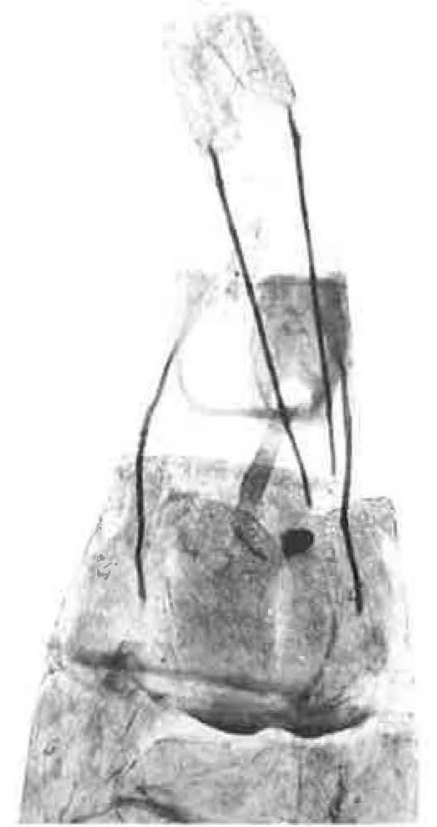

Fig. 21. Female genitalia of Scythris cretacella (holotype).

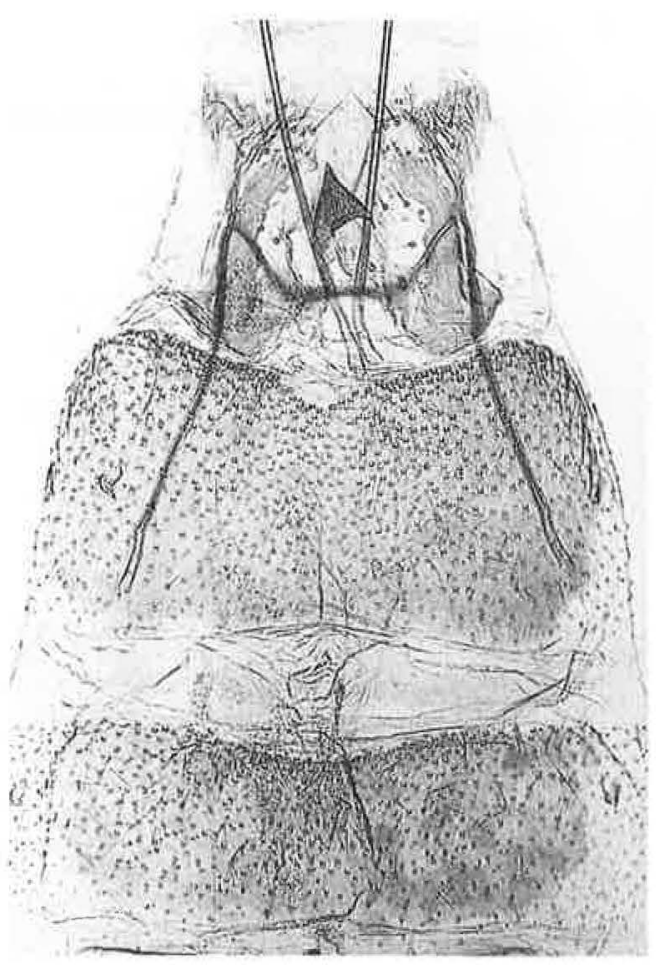

Fig. 32. Female genitalia of Scythris karinupponeni (paratype). 


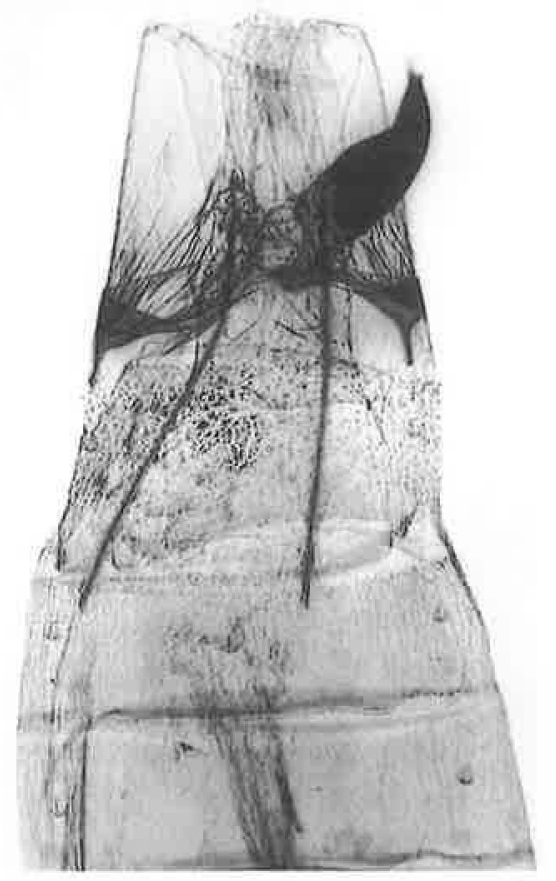

Fig. 36. Female genitalia of Scythris luxatiella (paratype).

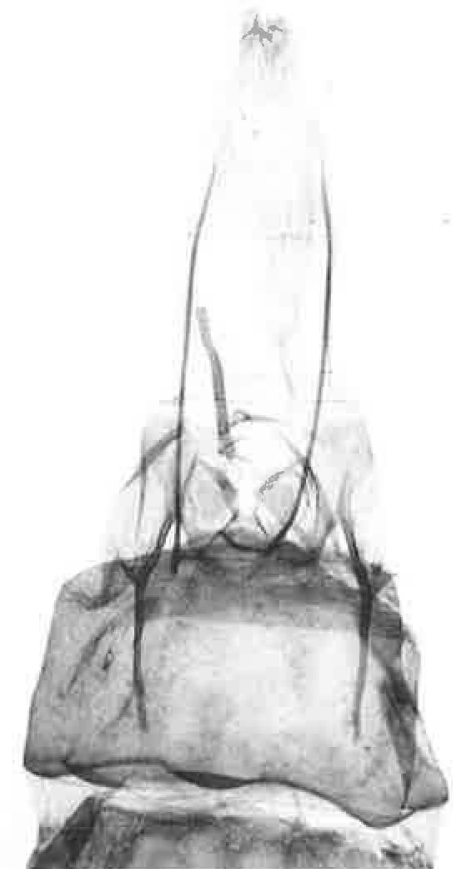

Fig. 40. Female genitalia of Scythris olschwangi (paratype).

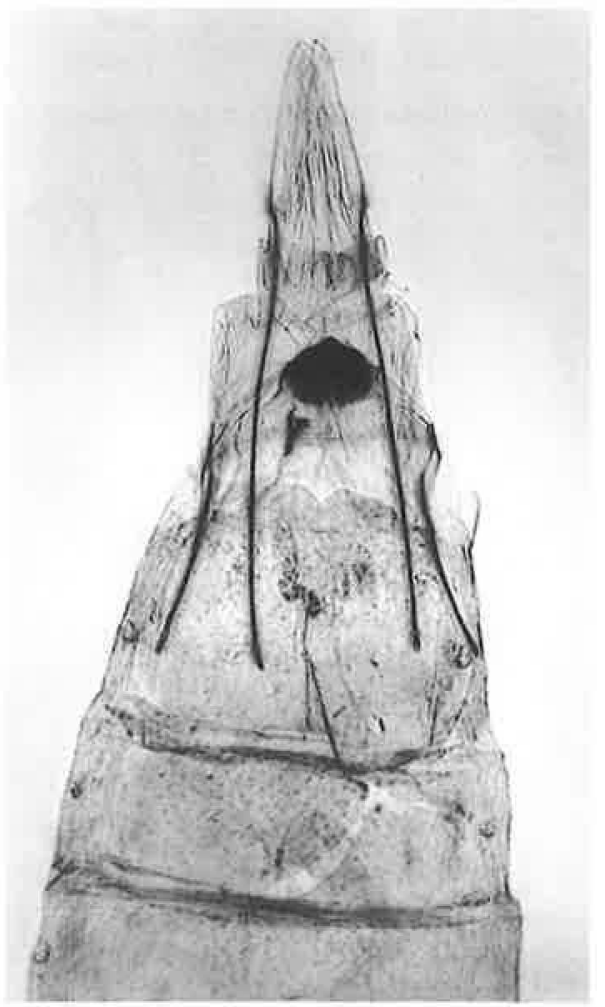

Fig. 48. Female genitalia of Scythris remexella (paratype).
Fig. 44. Female genitalia of Scythris perlucidella (paratype).

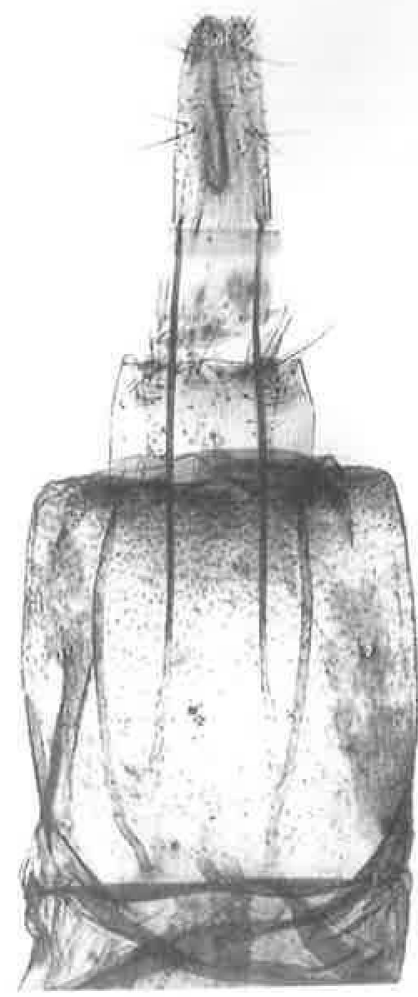


34

Nupponen et al.: The scythridid fauna of the southern - ENTOMOL. FENNICA Vol. 11

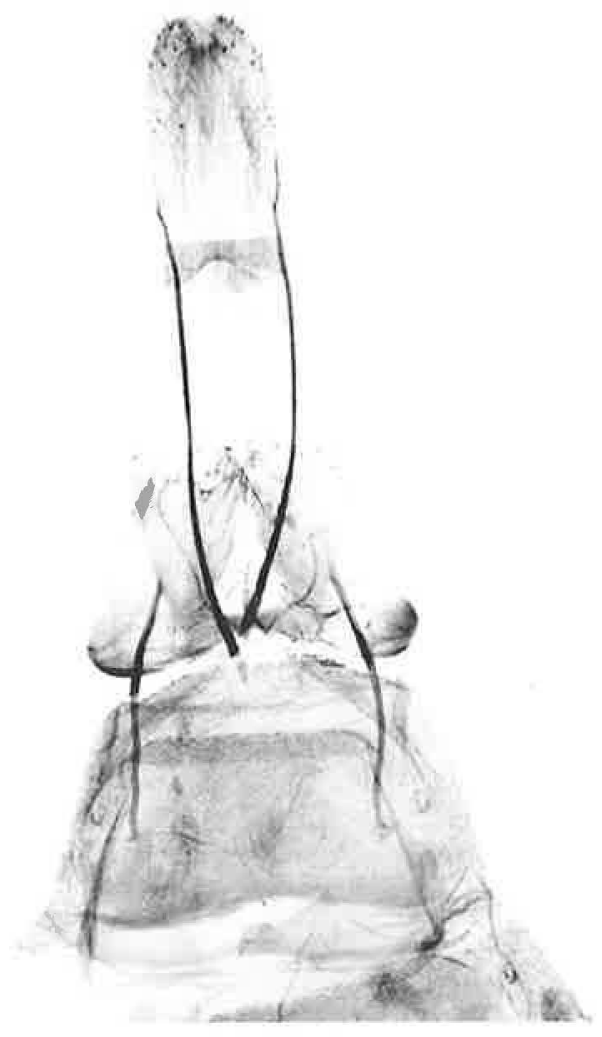

Fig. 52. Female genitalia of Scythris sublaminella (paratype).

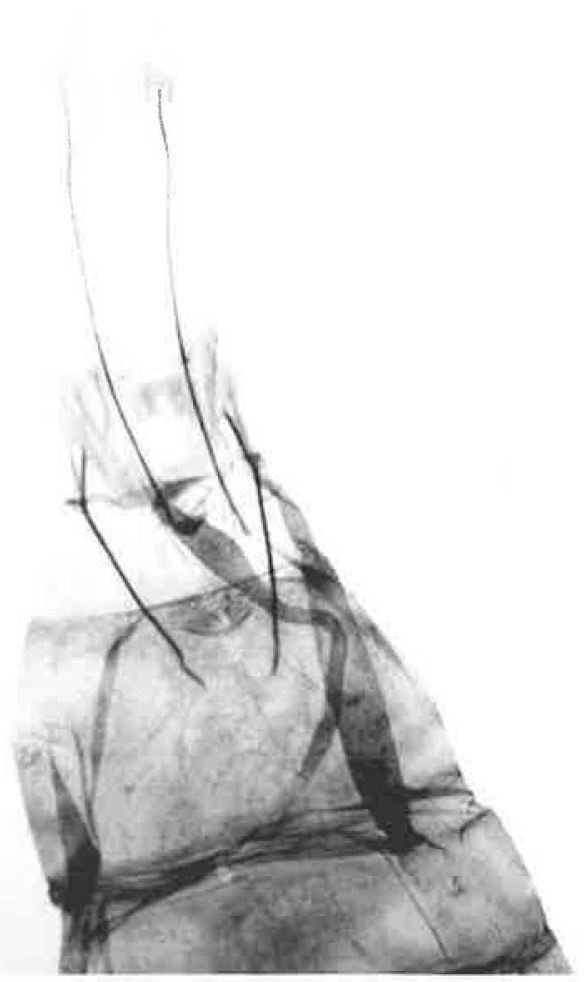

Fig. 54. Female genitalia of Scythris sp.

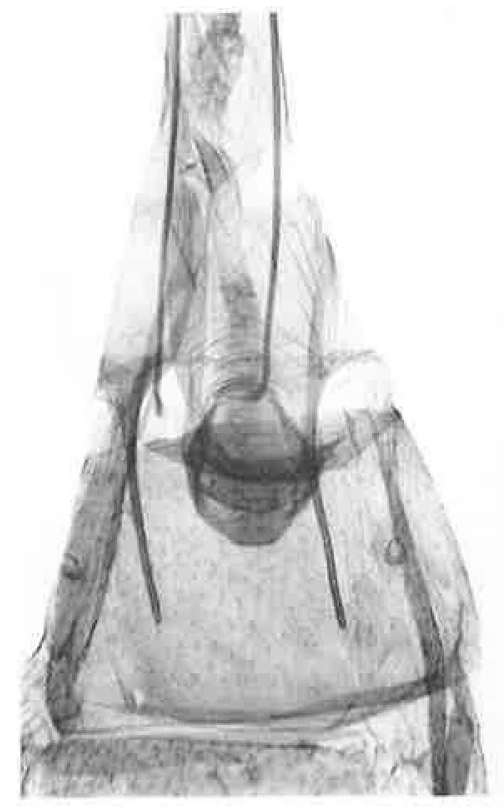

Fig. 7. Female genitalia of Scythris acipenserella (paratype). 